Rhode Island College

Digital Commons @ RIC

$12-1-2019$

\title{
The Effect of Positive End Expiratory Pressure (PEEP) with Recruitment Maneuvers on Atelectasis in Obese Patients Undergoing Abdominal Surgery: A Systematic Review
}

Jon Cerami

Follow this and additional works at: https://digitalcommons.ric.edu/etd

Part of the Nursing Commons

\section{Recommended Citation}

Cerami, Jon, "The Effect of Positive End Expiratory Pressure (PEEP) with Recruitment Maneuvers on Atelectasis in Obese Patients Undergoing Abdominal Surgery: A Systematic Review" (2019). Master's Theses, Dissertations, Graduate Research and Major Papers Overview. 312.

https://digitalcommons.ric.edu/etd/312

This Major Paper is brought to you for free and open access by the Master's Theses, Dissertations, Graduate Research and Major Papers at Digital Commons @ RIC. It has been accepted for inclusion in Master's Theses, Dissertations, Graduate Research and Major Papers Overview by an authorized administrator of Digital Commons @ RIC. For more information, please contact digitalcommons@ric.edu. 



\section{THE EFFECT OF POSITIVE END EXPIRATORY PRESSURE (PEEP) WITH RECRUITMENT MANEUVERS ON ATELECTASIS IN OBESE PATIENTS UNDERGOING ABDOMINAL SURGERY: A SYSTEMATIC REVIEW}

A Major Paper Presented

by

Jon Cerami, RN, SRNA

Approved:

Committee Chairperson

Committee Members

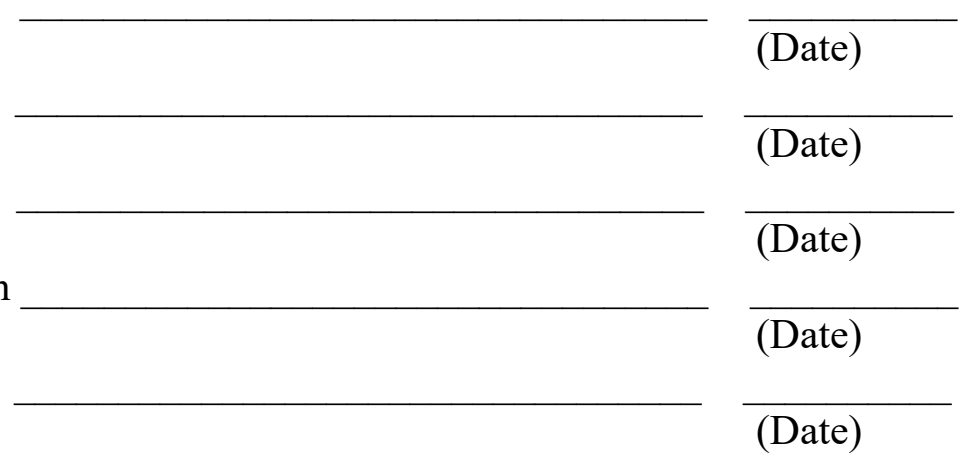

Director of Master's Program

Dean, School of Nursing 
THE EFFECT OF POSITIVE END EXPIRATORY PRESSURE (PEEP) WITH RECRUITMENT MANEUVERS ON ATELECTASIS IN OBESE PATIENTS UNDERGOING ABDOMINAL SURGERY: A SYSTEMATIC REVIEW

\author{
by
}

Jon Cerami

A Major Paper Submitted in Partial Fulfillment

of the Requirements for the Degree of

Master of Science in Nursing

in

The School of Nursing

Rhode Island College

2019 


\begin{abstract}
General anesthesia has a profound effect on respiratory dynamics in the obese population. Obesity can contribute to a decreased functional residual capacity, reduced lung volumes, and an increased closing capacity. Positioning and procedural requirements can further complicate the respiratory status of the obese patient. Surgical procedures in the obese population have an increased risk for the formation of atelectasis. Ventilation can be compromised due to atelectatic lung tissue and may result in post operative complications such as pneumonia, acute respiratory distress, hypoxia, a prolonged hospital stay, and the need for prolonged mechanical ventilation. Positive end-expiratory pressure (PEEP) is utilized in the operating room to increase arterial oxygenation, prevent airway collapse and expand alveoli during each breath. Alveolar recruitment maneuvers can be supplementary throughout surgical procedures to recruit and restore atelectatic lung tissue and prevent further formation of atelectasis. The purpose of this systematic review was to evaluate the effect of PEEP with recruitment maneuvers in obese patients undergoing abdominal surgery with general anesthesia. The theoretical framework that guided this systematic review was the Preferred Reporting Items for Systematic Review and MetaAnalysis (PRISMA) Statement. Randomized control trials included in this systematic review were appraised using the Critical Appraisal Skills Programme (CASP) to evaluate reliability. Alveolar recruitment maneuvers increase lung compliance, arterial oxygenation, and decrease complications associated with atelectasis formation. The use of PEEP with alveolar recruitment maneuvers should be employed for obese patients that undergo abdominal surgery with general anesthesia.
\end{abstract}




\section{Acknowledgements}

I would like to thank my family for their tremendous love, support, and perspective during this incredibly challenging and demanding journey. My friends who never lost touch and always seemed to grace me with a much needed conversation during the toughest times. My nursing professor, Dr. Ramdass who has been instrumental in guiding my nursing career (still waiting for my "Anesthesia for Dummies" textbook). There is certainly no way I could have been successful in this endeavor without you, your thoughts, your prayers, and your motivation. You inspire me to be the best nurse I can be and keep me grounded. I am forever grateful. I dedicate this chapter in life to my grandmother, may you forever stay in grandpa's arms in heaven. Jessie, thank you for bringing me home. E ricominciamo. 


\section{Table of Contents}

Background/Statement of the Problem ...................................................................... 1

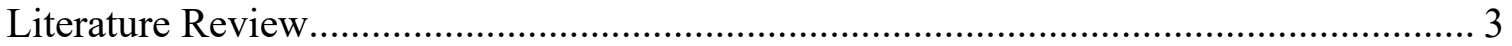

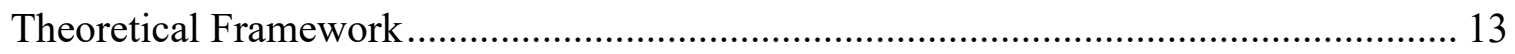

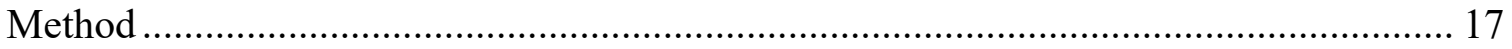

Results.................................................................... 21

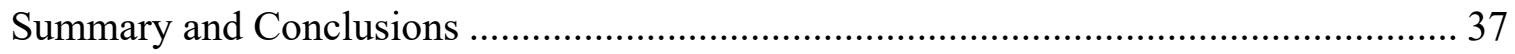

Recommendations and Implications for Advanced Nursing Practice .......................... 41

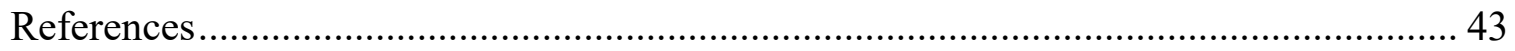

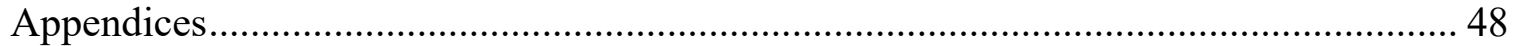


The Effect of Positive End Expiratory Pressure with Recruitment Maneuvers on Atelectasis in Obese Patients Undergoing Abdominal Surgery: A Systematic Review

\section{Background/Statement of the Problem}

Ventilation and perfusion are a complicated endeavor during surgery. There are many variables to consider when ventilating patients receiving general anesthesia. Strategies to optimize a patient's ventilation and perfusion during surgery and after receiving general anesthesia vary between institutions and licensed providers. Ventilation and perfusion mismatch can lead to increased healthcare costs, extended acute care requirements, and patient harm (Neligan, 2012). Establishing an appropriate ventilation and perfusion plan is vital to providing effective anesthesia care to each patient. General anesthesia can have adverse effects on alveoli and can compromise ventilation and gas exchange. Impaired gas exchange can be detrimental to the patient receiving general anesthesia perioperatively. Atelectasis is the main culprit of impaired gas exchange during surgical procedures (Coussa et al., 2004).

Bendixen, Smith and Mead (1964) define atelectasis as the partial or complete collapse of lung tissue. It can occur in up to $90 \%$ of non-obese patients immediately after induction of general anesthesia (Strandberg, Tokies, Brismar, Lundquist \& Hedenstierna, 1986). Due to alterations in pulmonary mechanics, obesity can increase the risk of developing atelectasis and hypoxemia, leading to further pulmonary complications and increased morbidity and mortality (Reinius et al., 2009).

Rusca et al. (2003) utilized computerized tomography scans to assess atelectasis formation in patients after induction of anesthesia. The study provided patients with PEEP before induction and after induction and found that PEEP with one recruitment 
maneuver reduced the formation and recurrence of atelectasis. Almarakbi, Fawzi and Alhashemi (2009) suggest that positive end-expiratory pressure with recruitment maneuvers is more beneficial and effective than the use of PEEP alone for patients undergoing surgery. According to Bluth et al. (2017), the studies and recommendations for the use of positive end-expiratory pressure and recruitment maneuvers during surgery stem from trials that include patients with a body mass index of below $35 \mathrm{~kg} / \mathrm{m} 2$. The Center for Disease Control and Prevention (CDC) (2016) defines obesity of an adult with a body mass index of above $30 \mathrm{~kg} / \mathrm{m} 2$. It is apparent that the studies and recommendations evaluated by Bluth et al. (2017) include only a portion of the obese population. Different variations in the usage of positive end-expiratory pressure (PEEP) with and without recruitment maneuvers have been explored. However, there appears to be a lack of evidence that supports a specific strategy to reduce atelectasis formation and pulmonary complications in obese patients.

The purpose of this systematic review is to evaluate the effects of the use of positive end-expiratory pressure with recruitment maneuvers on pulmonary function in obese patients undergoing abdominal surgery with general anesthesia.

Next, a review of the literature will be presented. 


\section{Literature Review}

A thorough review of the literature was performed utilizing PubMed, MEDLINE, and CINAHL. Multiple articles were found relevant for appraisal by using key search terms such as "Obesity," "Postoperative Complications," "Abdominal Surgery," "PEEP," "Recruitment Maneuvers," and "Atelectasis." Subheadings of the literature review will include atelectasis and postoperative complications, obesity, positive end-expiratory pressure (PEEP), recruitment maneuvers (RM), PEEP and recruitment maneuvers in obese patients undergoing abdominal surgery, and ventilation strategies in obese patients.

\section{Atelectasis and Postoperative Complications}

General anesthesia can have profound effects on normal body function and depress the respiratory drive. As stated by Coussa et al. (2004), atelectasis is prominent in the majority of patients after receiving general anesthesia with the amount of atelectasis increased in obese patients. Congruently, with the pulmonary pathophysiology and dysfunction related to obesity, the effects of anesthesia in this patient population can become problematic. Rothen, Sporre, Engberg, Wegenius and Hedenstierna (1993) define atelectasis as "the collapse of lung tissue, which significantly decreases lung volume." At normal atmospheric pressure at sea level, the air is mostly nitrogen and approximately 21 percent oxygen (Hall, 2016). Nitrogen is lighter in weight than oxygen and is essential to help keep alveoli from collapsing (Hall, 2016). Before induction of anesthesia, it is necessary to pre-oxygenate patients with a high fraction of inspired oxygen (FiO2) to maintain oxygen reserves while the patient is sedated or paralyzed (Miller, 2015). Patients breathing a high fraction of inspired oxygen, which occurs during mechanical ventilation, are likely to develop more atelectasis because the oxygen replaces normally 
inspired nitrogen which helps keep the alveoli open (Rothen et al., 1993). This is called absorptive atelectasis. Atelectasis can lead to further complications in post-operative patients including pneumonia, respiratory failure, and the exacerbation of underlying chronic lung disease (Qaseem et al., 2006). Regardless of weight, atelectasis occurs regularly after the induction of anesthesia and continues through the postoperative period (Talab et al., 2009). With a wide array of potential postoperative complications, anesthesia professionals must be vigilant in their practice to identify measures that could potentiate these complications after surgery. Hodgson, Murphy and Hart (2015) specify that obese patients are at higher risk than non-obese patients in developing atelectasis, postoperative acute respiratory failure, prolonged mechanical ventilation dependency and weaning difficulty, and a higher incidence of pneumonia. Standard ventilation strategies that include PEEP and RM are poorly defined for adult human obese patients, and with the risks associated with the ventilation of this population of patients, the development of evidence-based strategies are necessary.

\section{Obesity}

The Center for Disease Control and Prevention (2016) define overweight and obesity as a weight that is greater than what is considered healthy in relation to a given height. Body mass index (BMI) is a measure of a person's weight, in kilograms, in relation to the square of their height, in meters (CDC, 2016). According to the CDC (2016), there are more direct ways to measure body fat that include skinfold thickness, bioelectrical impedance, densitometry, dual-energy x-ray absorptiometry, and isotope dilution. Body mass index correlates with the results from these more direct, sometimes invasive or radioactive measurements. BMI is a simple screening tool that can measure 
the potential for procedural risks associated with obesity or those who are underweight. It can guide the assessment of whether a patient is underweight, healthy weight, overweight, obese, and morbidly obese. The indexes are measured in kilograms per meter squared $(\mathrm{Kg} / \mathrm{m} 2)$. An index below 18.5 is indicative of an underweight adult. An index between 18.5 and 24.9 indicates an adult of normal or healthy weight, an index between 25.0 and 29.9 indicates that an adult is overweight, an index above 30 indicates obesity, and an index above 40 signifies morbid obesity.

As reported by Whitlock et al. (2009), obesity is associated with an increased rate of mortality from multiple classifications of organ dysfunction and disease process. Nepogodiev et al. (2015) conducted a multicenter, observational study to determine the role of obesity as a risk factor for complications associated with surgical procedures. Obesity is associated with comorbidities such as cardiac disease, diabetes, cancer of the colon, and esophagus and increased risk of surgical site infection and thromboembolism (Nepogodiev et al, 2015).

Pulmonary dysfunction is quite profound in the obese patient. Higher residual lung volume, ventilation and perfusion abnormalities, decreased lung compliance and increased chest wall impedance, depressed ventilatory drive, bronchospasm and reduced strength and endurance of the respiratory muscles have all been reported to affect obese patients (Whitlock et al., 2009). According to Aldenkortt, Lysakowski, Elia, Brochard and Tramer (2012), these difficulties in pulmonary function and changes associated with obesity can lead to complications with mechanical ventilation during general anesthesia. The use of recruitment maneuvers (described below) can optimize oxygenation, gas exchange, and pulmonary function, and are expected to reduce the risks of postoperative 
pulmonary complications for patients undergoing general anesthesia (Aldenkortt et al., 2012). However, evidence regarding these ventilation strategies with PEEP and RM is limited.

\section{Recruitment Maneuvers}

An awake and spontaneously breathing adult will utilize a sigh breath multiple times per hour (Bendixen, Smith \& Mead, 1964). The sigh breath is a homeostatic reflex that results in an increase in inspiratory pressure as a result of a complex mediation of vagal input and peripheral chemoreceptor compliance (Bartlett, 1971). This vital reflex maintains pulmonary compliance and recruits alveoli to decrease the formation of atelectasis (Bartlett, 1971). General anesthesia compromises physiologic respiratory mechanics resulting in atelectasis due to the increased fraction of inspired oxygen, the administration of the sedative and paralytic medications, and the elimination of the sigh breath due to the sedative and paralytic effects. Patients undergoing general anesthesia may benefit from a recruitment maneuver which would provide a similar result to a physiologic sigh breath.

Miller (2015) describes alveolar recruitment as an increase in functional residual capacity due to the reinflation of collapsed alveoli. Hedenstierna and Rothen (2000) describe alveolar recruitment maneuvers (ARM), or recruitment maneuvers (RM), as vital capacity breaths, double tidal volume breaths and sigh breaths. Recruitment maneuvers are used to recruit alveoli, increase lung area to facilitate gas exchange, and increase alveolar oxygenation by sustaining an increase in airway pressure (Hedenstierna \& Rothen, 2000). Hartland, Newell and Damico (2014) performed a retrospective analysis on the use of recruitment maneuvers and found that out of six studies, only one 
appeared to display a statistically significant reduction in post-operative complications from the use of recruitment maneuvers. However, many of the studies analyzed by Hartland et al. (2014) had different values of sustained pressure used for a recruitment maneuver. The statistically significant results were associated with a recruitment maneuver of $40 \mathrm{cmH} 2 \mathrm{O}$ of continuous positive end-expiratory pressure (PEEP) for up to 15 seconds. Hartland et al. (2014), established that recruitment maneuvers were especially beneficial in subsets of patients that were at greater risk of experiencing perioperative atelectasis, such as obese patients.

\section{Positive End Expiratory Pressure (PEEP)}

Positive airway pressure therapy utilizes airway pressures above normal ambient pressure during inspiration and exhalation to optimize pulmonary and respiratory function (Miller, 2015). Positive pressure applied during inspiration is frequently referred to as positive pressure ventilation (PPV), while positive pressure applied during exhalation is commonly referred to as positive end-expiratory pressure (PEEP) (Miller, 2015). PPV would be utilized when using a mask or airway device to apply manual or mechanical ventilation to achieve appropriate tidal volume. PEEP is the alveolar pressure above atmospheric pressure that exists at the end of expiration. There are two types of PEEP, applied or extrinsic PEEP, and auto or intrinsic PEEP. Extrinsic PEEP is applied by mechanical ventilation, while intrinsic PEEP is secondary to incomplete expiration (Miller, 2015). Intrinsic PEEP is also referred to as "air trapping".

Maintaining consistent oxygen flow and carbon dioxide exchange through the pulmonary circuit is vital for hemodynamic stability (Miller, 2015). Positive pressure therapy is necessary when certain abnormal cardiopulmonary conditions arise. Apnea or 
any ventilatory pattern inconsistent with sustaining life, acute ventilatory failure, and impending ventilatory failure are three clinically evident situations in which positive pressure therapy via mechanical ventilation is indicated (Miller, 2015). Mechanical ventilation is also necessary when general anesthesia is administered such as for a surgical procedure. In these cases, mechanical ventilatory support functions to maintain adequate minute ventilation (relationship of tidal volume and respiratory rate over one minute), prevent air trapping, avoid airway collapse and maintain adequate oxygenation (Acosta, Santisbon \& Varon, 2007). Applied positive end-expiratory pressure can help prevent airway collapse and allow the more natural expansion of alveoli during each breath (Acosta et al., 2007). Consequently, PEEP appears to impede the development of atelectasis, after administration of general anesthesia, by keeping the alveoli open and maintaining appropriate oxygen and carbon dioxide exchange (Reinus et al., 2009).

\section{PEEP and Recruitment Maneuvers in Obese Patients Undergoing Abdominal}

\section{Surgery}

Obese patients are at a higher risk than non-obese patients to develop postoperative atelectasis after having laparoscopic surgery (Talab et al., 2009). Talab et al. (2009) studied 66 adult patients between ages 20 and 50 with body mass indexes between 30 and $50 \mathrm{~kg} / \mathrm{m} 2$ undergoing laparoscopic bariatric surgery. Patients were divided into three groups according to the recruitment maneuver used, and each consisted of 22 patients. The recruitment maneuver in this study was defined as the application of 40 $\mathrm{cmH} 2 \mathrm{O}$ of pressure for seven to eight seconds. Chest computed tomographic (CT) scans were assessed pre- and post-operatively to evaluate for atelectasis. CT scan can measure lung volumes in all or part of the lung and is a more sensitive study in detecting 
atelectasis than X-ray (Miller, 2015). The study concluded that the group that received a PEEP of $10 \mathrm{cmH} 2 \mathrm{O}$ with a recruitment maneuver of $40 \mathrm{cmH} 2 \mathrm{O}$ for seven to eight seconds maintained better oxygenation intraoperatively and postoperatively and had lower atelectasis scores as demonstrated by the chest CT scan. The two groups that used zero or $5 \mathrm{cmH} 2 \mathrm{O}$ of PEEP showed no differences in oxygenation or prevention of atelectasis.

The study by Coussa et al. (2004) recruited 23 morbidly obese patients between the ages of 20 and 65 years old who were scheduled for bariatric surgery. Patients who had a BMI of equal to or above $35 \mathrm{~kg} / \mathrm{m} 2$ were included. The aim of this study was to identify whether applying positive airway pressure during the induction of general anesthesia would prevent atelectasis formation despite using large concentrations of oxygen (Coussa et al., 2004). Two groups were evaluated. The PEEP group received continuous positive airway pressure (CPAP) during the administration of oxygen for 5 minutes. After anesthesia was induced in this group, they were ventilated with PEEP by face mask for 5 minutes prior to intubation. The control group followed the same induction procedure, however, without the use of CPAP or PEEP. The arterial blood samples obtained during two separate instances during surgery showed a significantly higher oxygen level in the group receiving PEEP, and the CT scans showed a significant increase in atelectasis immediately after intubation. It is important to note, however, that atelectasis was more profound in the control group. Coussa et al. (2004) conclude that the percentage of oxygen can significantly influence atelectasis formation. If low percentages of oxygen or FiO2 are used, then no atelectasis will occur. The danger in that technique is it can cause patients to decrease their circulating oxygen levels significantly. 
A study by Reinius et al. (2009) also focused on the morbidly obese with a body mass index above 40. The study focused on whether recruitment maneuvers and PEEP had any effects on reducing atelectasis in morbidly obese patients. When the patients received PEEP, they received $10 \mathrm{cmH} 20$, and the recruitment maneuver required 55 cmH2O for 10 seconds. Computerized Tomography scans were also used in the study. CT scans were obtained while patients were awake, after induction of anesthesia and paralysis and when using different ventilator settings. Reinius et al. (2009) evaluated patient status with CT scans while using PEEP alone, zero end-expiratory pressure, and a recruitment maneuver and lastly, a recruitment maneuver and PEEP.

The evaluation of oxygenation showed that patients who received PEEP and recruitment maneuver had a sustained increased in circulating oxygenation compared to those who did not. In addition, the same group had increased respiratory compliance as compared with their counterparts, which prevented atelectasis.

\section{Ventilation Strategies in Obese Patients.}

Mechanically ventilated patients in the intensive care unit, and the operating room require unique strategies and maintenance to promote optimization of pulmonary function. There are limited studies defining ventilation techniques to prevent postoperative pulmonary complications such as acute lung injury (ALI) and acute respiratory distress syndrome (ARDS) in obese patients. One study which does focus on demonstrating better ventilation practices and the factors associated with complications in obese patients was conducted by Jaber et al. (2012). Prior to the study, similar multicenter studies failed to include certain types of obese patients in a surgical setting receiving general anesthesia. 
The study conducted by Jaber et al. (2012) included 2,161 patients after exclusion criteria from 49 hospitals with 335 patients above $30 \mathrm{~kg} / \mathrm{m} 2$ and 1,826 below $30 \mathrm{~kg} / \mathrm{m} 2$. The average tidal volume used for ideal body weight was $8.8 \mathrm{ml} / \mathrm{kg}$, and no PEEP was used in most of the cases (81\%). However, obese patients were usually ventilated with higher tidal volumes in this study. The reasoning for this was not made clear in the study, aside from mentioning that it has been a method proposed in previous studies and that obese patients are at risk for lower arterial oxygenation during general anesthesia. A recruitment maneuver, which was not fully defined in the study, was applied in only seven percent of the patient population and more so in the obese patients. Jaber et al. (2012) concluded that there is a degree of overestimation of ideal body weight, especially in obese patients which can lead to inappropriately high tidal volumes leading patients to be at risk for ventilator-associated lung injuries. Only initial ventilator settings were evaluated, and the anesthesiologists in the cases may have changed the settings based on diagnostics during the procedures. While the study mentions protective ventilation strategies to prevent pulmonary complications in patients, the conclusion was that there are no recommendations for optimal tidal volume, positive end-expiratory pressure, or recruitment maneuvers.

Aldenkortt et al. (2012) conducted a systematic review and meta-analysis of ventilation strategies in obese patients undergoing surgery. Thirteen studies of more than 500 patients were reviewed and analyzed. Definitions, and reporting of conclusions related to tidal volume, PEEP, and recruitment maneuvers varied. Studies from 10 different countries published between 1978 and 2011 were included and demonstrated multiple variations of ventilation strategies. Various types of surgeries were presented in 
the data collected. Adding recruitment maneuvers to PEEP was found to increase pulmonary compliance and improved oxygenation, thereby preventing atelectasis. Surprisingly, as mentioned in many previous articles, the study by Aldenkortt et al. (2012) found no significant differences in using higher or lower tidal volumes in preventing atelectasis and lung compliance.

There continues to be a growing need to determine optimal ventilation strategies to prevent pulmonary complications in obese patients undergoing surgery. Pulmonary complications in this population appear to result from ventilation and perfusion strategies during the induction and duration of anesthesia. While many variables and comorbidities can play significant roles in ventilation strategies, research is needed to determine optimal strategies and support the standardization of practices among anesthesia providers to decrease pulmonary and extra-pulmonary complications postoperatively. Standardized strategies for intraoperative management of the obese patient remains poorly defined. While individualized care is promoted and always considered, evidencebased strategies to prevent atelectasis are needed.

Next, the Theoretical Framework will be discussed. 


\section{Theoretical Framework}

Inadequate reporting and bias were found to be a common problem among many published meta-analyses. During this time many popular medical journals did not assess scientific criteria consistently and they did not consistently uphold quality and validity standards. It was in 1996 that an international group developed the Quality of Reporting Meta-Analysis (QUOROM) statement to provide a better process of reporting metaanalyses and randomized control trials (Moher, Liberati, Tetzlaff \& Altman, 2009). QUOROM incorporated a checklist and flow diagram to maintain consistency, accountability, and quality throughout the assessment process. This statement was further revised and evolved into the Preferred Reporting Items for Systematic Reviews and Meta-Analyses (PRISMA) statement in 2009 (Moher et al., 2009). According to Moher et al. (2009), the PRISMA statement allows researchers to critically appraise published systematic reviews.

PRISMA is a 27-item checklist (Table 1) and a four-phase flow diagram (Figure 1) that was applied to assess systematic reviews and meta-analysis for bias, data collection, analysis, and eligibility criteria. The checklist and flow diagram seek to limit bias, improve validity and clarity, and ensure a methodical approach to the critical appraisal of published systematic reviews. The checklist focuses on seven aspects that should be appraised for each systematic review or meta-analysis. These aspects for appraisal include title, abstract, introduction, methods, results, discussion, and funding. Appraisal of each aspect allows for a transparent and consistent appraisal of the research. The PRISMA statement is widely employed and is essential to the analysis of systematic reviews. As the accepted standard for the evaluation of systematic reviews and meta- 
analysis, the PRISMA framework and checklist was used to support this systematic review. 


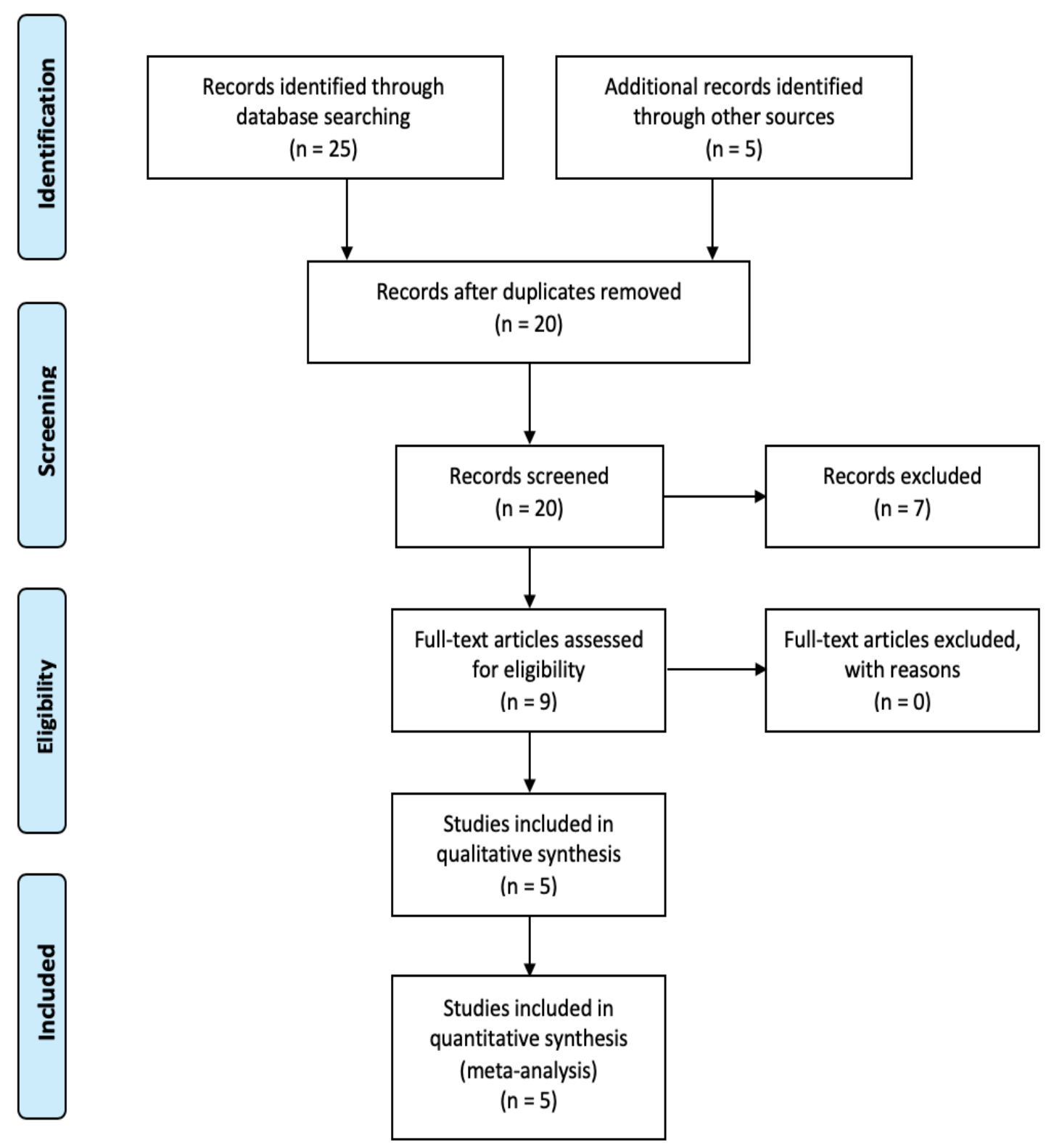

Figure 1. PRISMA flow diagram (Moher et al., 2009) 
Table 1. PRISMA 27-item checklist

\begin{tabular}{|c|c|c|c|}
\hline Section/Topic & \# & Checklist Item & $\begin{array}{l}\text { Reported on } \\
\text { Page \# }\end{array}$ \\
\hline \multicolumn{4}{|l|}{ TITLE } \\
\hline Title & 1 & Identify the report as a systematic review, meta-analysis, or both. & \\
\hline \multicolumn{4}{|l|}{ ABSTRACT } \\
\hline Structured summary & 2 & $\begin{array}{l}\text { Provide a structured summary including, as applicable: background; objectives; data sources; study eligibility } \\
\text { criteria, participants, and interventions; study appraisal and synthesis methods; results; limitations; conclusions } \\
\text { and implications of key findings; systematic review registration number. }\end{array}$ & \\
\hline \multicolumn{4}{|l|}{ INTRODUCTION } \\
\hline Rationale & 3 & Describe the rationale for the review in the context of what is already known. & \\
\hline Objectives & 4 & $\begin{array}{l}\text { Provide an explicit statement of questions being addressed with reference to participants, interventions, } \\
\text { comparisons, outcomes, and study design (PICOS). }\end{array}$ & \\
\hline \multicolumn{4}{|l|}{ METHODS } \\
\hline Protocol and registration & 5 & $\begin{array}{l}\text { Indicate if a review protocol exists, if and where it can be accessed (e.g., Web address), and, if available, provide } \\
\text { registration information including registration number. }\end{array}$ & \\
\hline Eligibility criteria & 6 & $\begin{array}{l}\text { Specify study characteristics (e.g., PICOS, length of follow-up) and report characteristics (e.g., years considered, } \\
\text { language, publication status) used as criteria for eligibility, giving rationale. }\end{array}$ & \\
\hline Information sources & 7 & $\begin{array}{l}\text { Describe all information sources (e.g., databases with dates of coverage, contact with study authors to identify } \\
\text { additional studies) in the search and date last searched. }\end{array}$ & \\
\hline Search & 8 & $\begin{array}{l}\text { Present full electronic search strategy for at least one database, including any limits used, such that it could be } \\
\text { repeated. }\end{array}$ & \\
\hline Study selection & 9 & $\begin{array}{l}\text { State the process for selecting studies (i.e., screening, eligibility, included in systematic review, and, if applicable, } \\
\text { included in the meta-analysis). }\end{array}$ & \\
\hline Data collection process & 10 & $\begin{array}{l}\text { Describe method of data extraction from reports (e.g., piloted forms, independently, in duplicate) and any } \\
\text { processes for obtaining and confirming data from investigators. }\end{array}$ & \\
\hline Data items & 11 & $\begin{array}{l}\text { List and define all variables for which data were sought (e.g., PICOS, funding sources) and any assumptions and } \\
\text { simplifications made. }\end{array}$ & \\
\hline $\begin{array}{l}\text { Risk of bias in individual } \\
\text { studies }\end{array}$ & 12 & $\begin{array}{l}\text { Describe methods used for assessing risk of bias of individual studies (including specification of whether this was } \\
\text { done at the study or outcome level), and how this information is to be used in any data synthesis. }\end{array}$ & \\
\hline Summary measures & 13 & State the principal summary measures (e.g., risk ratio, difference in means). & \\
\hline Synthesis of results & 14 & $\begin{array}{l}\text { Describe the methods of handling data and combining results of studies, if done, including measures of } \\
\text { consistency }\left(e . g ., I^{2}\right) \text { for each meta-analysis. }\end{array}$ & \\
\hline Risk of bias across studies & 15 & $\begin{array}{l}\text { Specify any assessment of risk of bias that may affect the cumulative evidence (e.g., publication bias, selective } \\
\text { reporting within studies). }\end{array}$ & \\
\hline Additional analyses & 16 & $\begin{array}{l}\text { Describe methods of additional analyses (e.g., sensitivity or subgroup analyses, meta-regression), if done, } \\
\text { indicating which were pre-specified. }\end{array}$ & \\
\hline \multicolumn{4}{|l|}{ RESULTS } \\
\hline Study selection & 17 & $\begin{array}{l}\text { Give numbers of studies screened, assessed for eligibility, and included in the review, with reasons for exclusions } \\
\text { at each stage, ideally with a flow diagram. }\end{array}$ & \\
\hline Study characteristics & 18 & $\begin{array}{l}\text { For each study, present characteristics for which data were extracted (e.g., study size, PICOS, follow-up period) } \\
\text { and provide the citations. }\end{array}$ & \\
\hline Risk of bias within studies & 19 & Present data on risk of bias of each study and, if available, any outcome-level assessment (see Item 12). & \\
\hline Results of individual studies & 20 & $\begin{array}{l}\text { For all outcomes considered (benefits or harms), present, for each study: (a) simple summary data for each } \\
\text { intervention group and (b) effect estimates and confidence intervals, ideally with a forest plot. }\end{array}$ & \\
\hline Synthesis of results & 21 & Present results of each meta-analysis done, including confidence intervals and measures of consistency. & \\
\hline Risk of bias across studies & 22 & Present results of any assessment of risk of bias across studies (see Item 15). & \\
\hline Additional analysis & 23 & Give results of additional analyses, if done (e.g., sensitivity or subgroup analyses, meta-regression [see Item 16]). & \\
\hline \multicolumn{4}{|l|}{ DISCUSSION } \\
\hline Summary of evidence & 24 & $\begin{array}{l}\text { Summarize the main findings including the strength of evidence for each main outcome; consider their } \\
\text { relevance to key groups (e.g., health care providers, users, and policy makers). }\end{array}$ & \\
\hline Limitations & 25 & $\begin{array}{l}\text { Discuss limitations at study and outcome level (e.g., risk of bias), and at review level (e.g., incomplete retrieval of } \\
\text { identified research, reporting bias). }\end{array}$ & \\
\hline Conclusions & 26 & $\begin{array}{l}\text { Provide a general interpretation of the results in the context of other evidence, and implications for future } \\
\text { research. }\end{array}$ & \\
\hline \multicolumn{4}{|l|}{ FUNDING } \\
\hline Funding & 27 & $\begin{array}{l}\text { Describe sources of funding for the systematic review and other support (e.g., supply of data); role of funders for } \\
\text { the systematic review. }\end{array}$ & \\
\hline
\end{tabular}

doi:10.1371/journal.pmed.1000097.t001 


\section{Method}

\section{Purpose, Clinical Question and Outcomes to be Examined}

The purpose of this systematic review is to evaluate whether the use of positive end-expiratory pressure with recruitment maneuvers affect the formation of atelectasis when compared with positive end-expiratory pressure without recruitment maneuvers in obese patients undergoing abdominal surgery.

\section{Inclusion/Exclusion Criteria}

This systematic review includes studies of adult human obese patients, above the age of 18 years, with a BMI $\geq 30 \mathrm{~kg} / \mathrm{m}^{2}$, receiving general anesthesia for different types of abdominal surgeries, where recruitment maneuvers were utilized to maintain oxygenation. Randomized control trials within the past 15 years were analyzed. Only studies presented in the English language were included. Exclusion criteria consist of studies of patients who had surgery without general anesthesia, or if recruitment maneuvers were not used during the procedure. Animal studies were excluded.

\section{Data Collection, Analysis, and Dissemination}

Each included study was evaluated by the population, intervention, comparison, and outcome (PICO). Table 2 shows the data table that was employed to compare the included randomized control trials. 
Table 2. Data Collection Template

\begin{tabular}{|l|l|}
\hline Study title & \\
\hline $\begin{array}{l}\text { Study } \\
\text { reference } \\
\text { citation }\end{array}$ & \\
\hline Population & \\
\hline Intervention & \\
\hline Comparisons & \\
\hline Aim of Study & \\
\hline $\begin{array}{l}\text { Inclusion } \\
\text { criteria }\end{array}$ & \\
\hline $\begin{array}{l}\text { Exclusion } \\
\text { criteria }\end{array}$ & \\
\hline $\begin{array}{l}\text { Outcome } \\
\text { measure(s) }\end{array}$ & \\
\hline Significance & \\
\hline
\end{tabular}

The Critical Appraisal Skills Programme (CASP) tool (CASP, 2017) was used for critical appraisal and analysis. See table 3. CASP is a checklist that guides appraising quality systematic reviews and can help in organizing one. The CASP tool (2017) is based on JAMA guidelines and is an 11-question checklist that allows the researcher to evaluate issues within research studies systematically and focus on questions that identify the validity, reliability, and consistency of the research. The CASP tool (2017) also includes devised checklists for critical appraisals of systematic reviews, randomized control trials, and qualitative studies. All of the appropriate critical appraisal tools were applied to evaluate the literature. 
Table 3. Critical Appraisal Skills Programme (CASP) Randomised Controlled Trials

\begin{tabular}{|c|c|c|c|c|}
\hline \multicolumn{5}{|l|}{ Study title } \\
\hline \multicolumn{5}{|l|}{ Study ID } \\
\hline \multirow{2}{*}{\multicolumn{2}{|c|}{ (A) Are the results of the trial valid? }} & Yes & $\begin{array}{l}\text { Can't } \\
\text { tell }\end{array}$ & No \\
\hline & & & & \\
\hline \multicolumn{2}{|c|}{ 2. Was the assignment of patients to treatments randomized? } & & & \\
\hline \multicolumn{2}{|c|}{ 3. Were patients, health workers and study personnel blinded? } & & & \\
\hline \multicolumn{2}{|c|}{ 4. Were the groups similar at the start of the trial? } & & & \\
\hline \multicolumn{2}{|c|}{$\begin{array}{l}\text { 5. Aside from the experimental intervention, were the groups treated } \\
\text { equally? }\end{array}$} & & & \\
\hline \multicolumn{2}{|c|}{$\begin{array}{l}\text { 6. Were all the patients who entered the trial properly accounted for } \\
\text { at its conclusion? }\end{array}$} & & & \\
\hline \multicolumn{5}{|c|}{ (B) What are the results? } \\
\hline \multicolumn{5}{|c|}{ 7. How large was the treatment effect? } \\
\hline \multicolumn{5}{|c|}{ 8. How precise was the estimate of the treatment effect? } \\
\hline \multicolumn{2}{|c|}{ (C) Will the results help locally? } & Yes & $\begin{array}{l}\text { Can't } \\
\text { tell }\end{array}$ & No \\
\hline \multicolumn{2}{|c|}{ 9. Can the results be applied in your context or to the local population? } & & & \\
\hline \multicolumn{2}{|c|}{ 10. Were all clinically important outcomes considered? } & & & \\
\hline \multicolumn{2}{|c|}{ 11. Are the benefits worth the harms and costs? } & & & \\
\hline
\end{tabular}

\section{Checklist}

A cross-study analysis was performed to evaluate the effect of positive end-

expiratory pressure, with and without recruitment maneuvers, on the formation of

atelectasis post-operatively. Data was entered in the table below (Table 4) and the results were dissected and analyzed. 
Table 4. Cross Study Analysis Template

\begin{tabular}{|l|l|}
\hline Study/Year & \\
\hline Cohort & \\
\hline Aim & \\
\hline Groups & \\
\hline $\begin{array}{l}\text { Post-operative } \\
\text { evaluation }\end{array}$ & \\
\hline
\end{tabular}

Next, the study results will be presented. 


\section{Results}

Twenty-five studies were identified through the initial database search with five additional studies identified through other sources. Duplicate records were removed, and remaining studies were screened for eligibility. Based on the inclusion and exclusion criteria, five studies were included in the systematic review. The PRISMA flow diagram, illustrated in Figure 1, displays the identification phase of the systematic review.

The five studies are presented in chronological order with the oldest study first (Whalen et al., 2006, Chalhoub et al., 2007, Reinius et al., 2009, Talab et al., 2009, Futier et al., 2011). Each study is summarized in data collection tables (Appendix A) and appraised using the Critical Appraisal Skills Programme (CASP) Randomised Controlled Trials Checklist (Appendix C). A cross-study analysis is also formulated (Appendix B) for evaluation.

\section{Individual Study Summaries and Critical Analysis}

The Whalen et al. (2006) trial (Appendix A-1), a prospective, randomized study, examined 20 morbidly obese patients $25-65$ years of age with body mass index above 40 $\mathrm{kg} / \mathrm{m} 2$ and ASA physical status of 2 or 3 . The study aimed to assess how recruitment maneuvers and positive end-expiratory pressure effect respiratory mechanics, hemodynamics, and oxygenation. The subjects were undergoing laparoscopic bariatric Roux-en-Y operations at St. Mary’s Hospital in Rochester, MN. Patients were excluded that were younger than 25 years old and older than 65 years, below a BMI of $40 \mathrm{~kg} / \mathrm{m} 2$, or who had significant preoperative pulmonary disease, active asthma, and receiving home oxygen therapy. 
A noninvasive cardiac output monitor (NICO2; Novametrix Medical Systems, Inc, Wallingford, CT) was used to measure cardiac output. The monitor also measures mean and peak airway pressures, minute ventilation, expiratory tidal volume, and calculates respiratory system dynamic compliance, inspiratory airway resistance, and physiologic dead space to tidal volume ratios. Arterial blood pressures were directly monitored with an arterial line with a sensor, a part of Paratrend 7 monitoring system, to continuously monitor the partial pressure of oxygen $(\mathrm{PaO} 2)$, the partial pressure of $\mathrm{CO} 2$ (PaCO2) and $\mathrm{pH}$ values.

Anesthetic management was standardized for the patients. Ventilatory management was randomized as follows. In the control group $(n=10)$, the patients were ventilated with $50 \%$ oxygen, tidal volume of $8 \mathrm{~mL} / \mathrm{kg}$ of ideal body weight, PEEP of 4 $\mathrm{cm} \mathrm{H} 2 \mathrm{O}$, inspiratory: expiratory ratio of $1: 2$, and an initial ventilatory rate of 8 breaths per minute. Respiratory rate and tidal volumes were adjusted, if required, to maintain $\mathrm{PaCO} 2$ between 45 and $50 \mathrm{mmHg}$, mild hypercapnia was permissive. Patients in the recruitment group $(n=10)$ were ventilated identically; however, after the initiation of pneumoperitoneum, a recruitment maneuver was performed by increasing the PEEP systematically. The recruitment maneuver took approximately 2 minutes to perform, starting with PEEP of $10 \mathrm{cmH} 2 \mathrm{O}$ for three breaths, then increasing to $15 \mathrm{cmH} 2 \mathrm{O}$ for three breaths and finally to $20 \mathrm{cmH} 2 \mathrm{O}$ for ten breaths. Subsequent recruitment maneuvers were performed whenever the $\mathrm{PaO} 2$ decreased more than $25 \mathrm{mmHg}$ more than maximal $\mathrm{PaO} 2$ achieved after the initial maneuver. All measurements were made with patients in the same position and baseline measurements were performed at least five minutes after induction of anesthesia, but before pneumoperitoneum was initiated. Further 
measurements were obtained five minutes after pneumoperitoneum was initiated and at 30, 60, and 120 minutes after baseline. A final measurement was recorded after pneumoperitoneum was released and 30 minutes after tracheal extubation.

Medical records and clinical notes were reviewed after the patient's discharge for the development of postoperative complications. These complications include pulmonary embolism, respiratory failure requiring mechanical ventilation or delayed tracheal extubation (more than 24 hours after surgery), pneumonia, new onset of fever and infiltrates associated with leukocytosis or leukopenia, purulent sputum or positive sputum culture, atelectasis requiring intervention (bronchoscopy), and length of hospitalization. The primary outcome variable included the ratio of arterial oxygen partial pressure to inspiratory oxygen concentration (PaO2/FIO2). Additionally, other variables were included that related to gas exchange, oxygenation, ventilation, respiratory mechanics, and hemodynamics. A P-value $<0.05$ was considered statistically significant.

In the Whalen et al. (2006) study, there were no significant differences in demographic characteristics, duration of operation, or the intraoperative use of opioids or fluids between the two groups. Patients in the recruitment group had a significantly higher intraoperative $\mathrm{PaO} 2 / \mathrm{FIO} 2$ ratio $(\mathrm{P}<0.01)$. Respiratory system compliance was increased considerably, when recruitment maneuvers were utilized, by approximately $40 \%$ at five minutes $(\mathrm{P}<0.05)$. However, at 30 minutes after recruitment, compliance declined and approached pre-recruitment values. After the pneumoperitoneum was released, compliance increased in both groups but was higher in the recruitment group than the control group $(\mathrm{P}<0.01)$. At 30 minutes after tracheal extubation, there was no significant difference in $\mathrm{PaO} 2 / \mathrm{FIO} 2$ between groups $(\mathrm{P}<0.57)$. Ventilatory requirements 
to maintain $\mathrm{PaCO} 2$ around $50 \mathrm{mmHg}$ were similar between groups. Peak inspiratory pressure and mean airway pressures were higher in the recruitment group $(\mathrm{P}<0.01)$. The length of hospitalization and the incidence of pulmonary complications were not significantly different between groups. One patient in the recruitment group had a pulmonary embolism, and two had respiratory failure. In the control group, one patient had respiratory failure, and one developed atelectasis requiring intervention.

Findings from this study suggest that a recruitment maneuver (RM) significantly improves oxygenation and respiratory mechanics in obese patients undergoing laparoscopic bariatric surgery. Study limitations include a small sample size $(n=20)$. The critical appraisal of the Whalen et al. (2006) trial (Appendix C-1) suggest that a recruitment maneuver is statistically significant to maintain oxygenation and respiratory mechanics during laparoscopic bariatric surgery, although the sample size was small with 20 patients. The study was also limited to a single center.

The Chalhoub et al. (2007) trial, a single-center, prospective, randomized study, included 52 morbidly obese patients, above the age of 18 years of age, with a body mass index above $40 \mathrm{~kg} / \mathrm{m} 2$, and are an ASA grade III scheduled for open bariatric surgery. The study aimed to assess the effects of recruitment maneuvers (labeled as vital capacity maneuver [VCM] in this study) followed by the addition of positive end-expiratory pressure on arterial oxygenation. Cardiac, pulmonary, and neurological diseases were considered as exclusion criteria.

Intraoperative monitoring included electrocardiography, radial artery pressure, pulse oximetry, capnography, urine output, rectal temperature and end-tidal CO2 (ETCO2). Respiratory rate was adjusted to maintain ETCO2 between $30-35 \mathrm{mmHg}$. 
Anesthetic management was standardized for the patients, and anesthetic drugs were calculated on ideal body weight. Patients were mechanically ventilated with a tidal volume of $10 \mathrm{~mL} / \mathrm{kg}$ of ideal body weight. A mixture of nitrous oxide and oxygen, instead of a mix of oxygen and medical air, was part of the anesthetic protocol for obese patients by the institution conducting the study. Patients were randomized into two groups. Group 1 utilized a PEEP of $8 \mathrm{mmHg}$ with the ventilation regimen. In Group 2, a recruitment maneuver was applied before adding a PEEP of $8 \mathrm{mmHg}$ to the ventilation regimen. The VCM was performed by inflating the lungs to a peak pressure of 40 $\mathrm{cmH} 2 \mathrm{O}$ and maintaining the pressure for 15 seconds. The VCM or PEEP or both was applied 10 minutes after abdominal opening and positioning of reverse Trendelenburg was established. PEEP was maintained throughout the procedure until tracheal extubation. Arterial blood gases, ETCO2, peak airway pressure, expired tidal volume, respiratory rate, mean arterial pressure and heart rate were measured in the two study groups before the application of VCM and/or PEEP (this time was referred to as T0 in the study), 10 minutes after the implementation of VCM and/or PEEP (this time was referred to as $\mathrm{T} 1$ in the study), and at the end of surgery before abdominal closure (this time was referred to as T2 in the study). A P-value $<0.05$ was considered statistically significant.

The two groups were comparable in demographic characteristics, surgical time, times between $\mathrm{T} 1$ and $\mathrm{T} 2$, fluid administration, urine output, extubation time, and postanesthesia care unit stay. Hemodynamic and ventilatory measurements, at T0, T1, and T2 saw no significant differences in heart rate, $\mathrm{PaCO}$, ETCO2, peak airway pressure, expired tidal volume, and respiratory rate in each group. Baseline $\mathrm{PaO} 2$ and $\mathrm{SaO} 2$ values were comparable between both groups. Alveolar-arterial oxygen gradient (A-aDO2) was 
calculated and measured in each group. In group $1, \mathrm{PaO} 2$ and $\mathrm{SaO} 2$ were significantly increased, and $\mathrm{A}-\mathrm{aDO} 2$ was decreased at $\mathrm{T} 2(\mathrm{P}<0.001)$. In group 2, $\mathrm{PaO} 2$ and $\mathrm{SaO} 2$ were increased considerably and $\mathrm{A}-\mathrm{aDO} 2$ decreased at both $\mathrm{T} 1$ and $\mathrm{T} 2(\mathrm{P}<0.001)$. Arterial oxygenation was significantly improved in Group 2 when compared with Group $1(\mathrm{P}<0.001)$.

The critical appraisal of the Chalhoub et al. (2007) trial (Appendix C-2) suggests that PEEP improves oxygenation in obese patients undergoing abdominal surgery, and the addition of a VCM further improves oxygenation compared to PEEP alone. However, in this study, only one VCM was used intra-operatively and the sample size and singlecenter nature of this study may limit the generalizability of the findings. The appraisal also suggests that not all clinically relevant outcomes were considered, such as measurement of lung volumes and respiratory mechanics, due to the unavailability of technical procedures or equipment to evaluate these measures.

The Reinius et al. (2009) trial, a single-blind randomized study, focused on 30 patients with a body mass index greater than $40 \mathrm{~kg} / \mathrm{m} 2$, ASA grade II or III, aged 25 to 54 years, scheduled for elective gastric bypass surgery were enrolled. The study aimed to evaluate whether a recruitment maneuver followed by PEEP would be the most efficient way to improve respiratory function in morbidly obese patients during general anesthesia and paralysis in the supine position. Exclusion criteria included age below 18 years, pregnancy, cardiac disease, and obstructive pulmonary disease (defined as forced expiratory volume below $80 \%$ of expected value).

Intraoperative monitoring included invasive arterial blood pressure, pulse oximetry, electrocardiography, end-tidal carbon dioxide concentration, airway pressures, 
tidal volume, and respiratory rate. An anesthetist experienced in the treatment of morbidly obese patients administered anesthesia. Anesthetic management was standardized for patients, and anesthetic medications were calculated using ideal body weight. Respiratory rate was adjusted to maintain ETCO2 at 34 to $41 \mathrm{mmHg}$. After anesthesia and tracheal intubation, patients were randomized into three intervention groups. The PEEP group received PEEP of $10 \mathrm{cmH} 2 \mathrm{O}$, the $\mathrm{RM}+\mathrm{ZEEP}$ group received a recruitment maneuver followed by zero end-expiratory pressure, and the RM+PEEP group received a recruitment maneuver followed by PEEP of $10 \mathrm{cmH} 2 \mathrm{O}$. The recruitment maneuver was performed by applying a pressure of $55 \mathrm{cmH} 2 \mathrm{O}$ and held for 10 seconds. The recruitment maneuver was disrupted only if there was a decrease in systolic blood pressure of more than $20 \%$. Measurements were obtained before induction of anesthesia, five minutes after induction and tracheal intubation, and five, 20, and 40 minutes after intervention. The local ethics committee at Uppsala University in Uppsala, Sweden, was consulted and permitted the authors to complete a maximum for two spiral computerized tomography (CT) scans in each patient. The aim was to investigate aeration of the lung at end-expiration in awake patients and in the anesthetized patient. For practical and technical reasons, only 23 of the 30 patients received the CT scans.

A recruitment maneuver followed by PEEP caused an increase in $\mathrm{PaO} 2 / \mathrm{FIO} 2$ ratio $(\mathrm{P}<0.0001)$ at five minutes and this increase was sustained at 20 and 40 minutes after the recruitment maneuver $(\mathrm{P}<0.0001)$. PEEP alone or zero end-expiratory pressure following a recruitment maneuver did not cause a significant change in the $\mathrm{PaO} 2 / \mathrm{FIO} 2$ ratio. The $\mathrm{PaO} 2 / \mathrm{FIO} 2$ ratio was reduced by approximately $40 \%$ after induction of anesthesia and paralysis $(\mathrm{P}<0.0001)$. A recruitment maneuver followed by PEEP caused 
an increase in respiratory compliance $(\mathrm{P}<0.0001)$. The atelectatic volume was measured before induction and five minutes after induction and was significantly increased in all three groups $(\mathrm{P}<0.0001)$, with no significant difference in developed atelectatic volume between the groups. The RM+PEEP group had an increased fractional amount of normally aerated tissue, decreased the amount of poorly aerated tissue, and reduced nonaerated tissue $(\mathrm{P}<0.0001)$. Finally, the $\mathrm{RM}+\mathrm{PEEP}$ group had a significantly reduced mean area of atelectasis and the reduced atelectasis was maintained at 20 minutes after the intervention $(\mathrm{P}<0.0001)$.

The critical appraisal of the Reinius et al. (2009) trial (Appendix C-3) suggests that a recruitment maneuver followed by PEEP is statistically significant in reducing atelectasis and improving oxygenation after the induction of anesthesia. All clinically important outcomes were reported. The groups were mostly similar at the start of the trial; however, the majority of the patients included in this study were female. The Reinius et al. (2009) study utilized a small sample size at a single setting.

The Talab et al. (2009) study, a prospective, double-blind, randomized trial, evaluated 66 adult obese patients with a body mass index between 30 and $50 \mathrm{~kg} / \mathrm{m} 2$, between the ages of 20 and 50 years, and scheduled to undergo laparoscopic bariatric surgery. The aim of this study was to evaluate the safety and efficacy of the vital capacity maneuver (VCM; recruitment maneuver) followed by different levels of PEEP used intraoperatively to prevent atelectasis post-operatively. Patients were excluded if they had been hospitalized for more than 24 hours prior to the surgical procedure, had a history of cardiac or respiratory disease, or had any clinical signs of cardiopulmonary 
disease (jugular vein distention, gallop rhythm, hepatomegaly, tibial edema, rales, or electrocardiogram changes).

Anesthetic management and intraoperative monitoring were standardized for the patients in this study, as well as, emergence and extubation criteria. Heart rate, noninvasive MAP, and arterial oxygen saturation were measured at eight different times during the procedure. These measurements were obtained before induction of anesthesia and breathing room air (T0), immediately after induction of anesthesia (T1), immediately after a vital capacity maneuver (T2), shortly after establishing pneumoperitoneum (T3), immediately after patient positioning (modified lithotomy position with reverse Trendelenburg)(T4), 30 minutes after establishing position (T5), 60 minutes after establishing positioning/end of procedure (T6), immediately after recovery area admission (T7), and before discharge from recovery area (T8). Arterial blood gas samples were obtained preoperatively and postoperatively, T0 and T8, respectively, to measure $\mathrm{PaO} 2$ and to calculate the alveolar-arterial $\mathrm{PaO} 2$ gradient $(\mathrm{A}-\mathrm{a} \mathrm{PaO} 2)$. Length of stay in recovery and the need for supplemental $100 \%$ oxygen or reintubation were recorded. Patients were randomly placed into three groups. Each group received a VCM with differing levels of PEEP. The pressure used for the VCM was not specifically stated; however, it is inferred that a pressure of $40 \mathrm{~cm} \mathrm{H} 2 \mathrm{O}$ was applied. The zero-end expiratory pressure $(Z E E P)$ group $(n=22)$ received the vital capacity maneuver for $7-8$ seconds after intubation plus ZEEP. The PEEP 5 group $(n=22)$ received the vital capacity maneuver for 7-8 seconds after intubation plus $5 \mathrm{cmH} 2 \mathrm{O}$ of PEEP. The PEEP 10 group $(n=22)$ received the vital capacity maneuver for $7-8$ seconds after intubation plus 10 cmH2O of PEEP. CT scans were performed on hospital admission and after discharge 
from the recovery area. Atelectasis was evaluated and classified into four types by radiologists aware of the experimental protocol, but not the patient group. The four types of atelectasis were based on thickness and included lamellar atelectasis $(<3 \mathrm{~mm})$, plate atelectasis $(3-10 \mathrm{~mm})$, segmental atelectasis $(>10 \mathrm{~mm}$ but less than a lobe), and lobar atelectasis (involving the entire lobe).

During the study, three patients in the ZEEP group, three patients in the PEEP 5 group, and two patients in the PEEP 10 group were excluded. Taleb et al. (2009) concluded that there was a significant decrease of postoperative A-a gradient in the PEEP 10 group compared with the ZEEP and PEEP 5 groups $(\mathrm{P}<0.05)$. Recovery time was also significantly shorter in the PEEP 10 group compared to the ZEEP and PEEP 5 groups $(\mathrm{P}<0.05)$. During the first 48 hours postoperatively, no significant desaturation, chest infection, or bronchospasm was identified in the PEEP 10 group. Postoperative CT scans showed that the PEEP 10 group had significantly less segmental and lobar atelectasis $(\mathrm{P}<0.05)$.

The critical appraisal of the Taleb et al. (2009) trial (Appendix C-4) suggests intraoperative management with a vital capacity maneuver followed by PEEP of 10 $\mathrm{cmH} 2 \mathrm{O}$ is more effective at preventing atelectasis than ZEEP or a VCM followed by PEEP of $5 \mathrm{cmH} 2 \mathrm{O}$. It is also associated with better oxygenation, a shorter recovery area stay, and fewer postoperative pulmonary complications in obese patients undergoing laparoscopic bariatric surgery. There were no statistically significant differences in age, demographic characteristics, ASA, duration of surgery, or BMI in the Taleb et al. (2009) study. All clinically important outcomes were reported. Study limitations include the small sample size and single-setting nature of the study. 
Futier et al. (2011) conducted a prospective, single-blind randomized study with seventy adult patients, ASA II-III and a BMI greater than or equal to $40 \mathrm{~kg} / \mathrm{m} 2$ scheduled for laparoscopic sleeve gastrectomy or Roux-en-Y gastric bypass surgeries. The aim of the study was to evaluate whether noninvasive positive pressure ventilation (NPPV) improves oxygenation and end-expiratory lung volume (EELV) better than conventional oxygenation methods at the induction of anesthesia. Additionally, to determine whether a recruitment maneuver applied after NPPV further improves respiratory function after the initiation of mechanical ventilation. Exclusion criteria included consent refusal, age younger than 18 years, severe cardiac failure, pregnancy, chronic obstructive pulmonary disease (defined as forced expiratory volume in 1 second less than $80 \%$ of expected value).

Intraoperative monitoring and anesthetic management were standardized for the patients involved in the study. Anesthetists with experience with the management of morbidly obese patients performed the anesthetic procedure. Arterial blood samples were taken minutes before and immediately after the preoxygenation trial, immediately after intubation and five minutes after the onset of mechanical ventilation at a PEEP of 10 cmH2O. End-tidal oxygenation (ETO2) and carbon dioxide (ETCO2) concentrations were measured with a calibrated analyzer. Arterial to end-tidal partial pressure of carbon dioxide (Pa-ETCO2) (an indicator of lung collapse and reopening that correlates with atelectatic lung area on CT scan) were recorded after five minutes of mechanical ventilation. A preoperative lung function test was performed 1-2 days before surgery in all patients, and EELV measurements were obtained. Peak airway pressure and plateau 
end-inspiratory airway pressure were recorded five minutes after the onset of mechanical ventilation.

Patients were randomly assigned to 3 groups, a conventional preoxygenation; spontaneous breathing with a facemask (CON group), NPPV (NPPV group), and NPPV $+\mathrm{RM}$ (NPPV + RM group). A recruitment maneuver followed NPPV after tracheal intubation in the NPPV + RM group. Spontaneous breathing at FIO2 of $100 \%$ was maintained in the CON group. In the NPPV and NPPV + RM groups, pressure support ventilation was adjusted to an expiratory tidal volume (VTe) of $8 \mathrm{ml} / \mathrm{kg}$, a PEEP level of 6-8 $\mathrm{cmH} 2 \mathrm{O}$, and an airway pressure of no more than $18 \mathrm{cmH} 2 \mathrm{O}$. FIO2 was also set at $100 \%$. A recruitment maneuver was applied with a continuous positive airway pressure of $40 \mathrm{cmH} 2 \mathrm{O}$ for 40 seconds.

Futier et al. (2011) found no significant difference in preoperative EELV between groups $(\mathrm{P}<0.96)$ or $\mathrm{PaO} 2$ values at baseline. After preoxygenation for five minutes, $\mathrm{PaO} 2$ was significantly higher in the NPPV and NPPV $+\mathrm{RM}$ groups $(\mathrm{P}<0.001)$. Mean ETO2 was higher in the NPPV and NPPV + RM groups $(\mathrm{P}<0.01)$. EELV was significantly higher in the NPPV and NPPV $+\mathrm{RM}$ groups $(\mathrm{P}<0.001)$. PaO2 was significantly higher in the NPPV $+\mathrm{RM}$ group $(\mathrm{P}<0.0001$ and $\mathrm{PaCO} 2$ significantly lower after the RM was applied $(\mathrm{P}=0.038)$. NPPV lowered Pa-ETCO2 $(\mathrm{P}<0.001)$ and with a RM further decreased Pa-ETCO2 ( $\mathrm{P}=0.024)$. Futier et al. (2011) calculated the static elastance of the respiratory system by dividing the difference between plateau endinspiratory airway pressure and end-expiratory pressure at a period of no flow (corrected for intrinsic PEEP), and VTe is the expiratory tidal volume (change in Paw/VTe). NPPV and NPPV + RM significantly lowered static elastance of the respiratory system (P 
$<0.0001)$ with a strong difference between the NPPV and NPPV $+\mathrm{RM}(\mathrm{P}<0.023)$.

Compared with NPPV alone, NPPV + RM significantly lowered plateau end-inspiratory airway pressure $(\mathrm{P}=0.012)$. EELV was significantly higher in the NPPV and NPPV + RM groups $(\mathrm{P}<0.001)$, while NPPV + RM further increased EELV $(\mathrm{P}<0.03)$.

The critical appraisal of the Futier et al. (2011) trial (Appendix C-5) suggests that $\mathrm{NPPV}+\mathrm{RM}$ increase EELV and decrease static elastance of the respiratory system. The $\mathrm{PaO} 2$ remained significantly higher in the groups that utilized positive pressure ventilation. According to Futier et al. (2011), the study design did not evaluate the extent of alveolar recruitment with the recruitment maneuver. However, they associate the increase in EELV (of approximately 30\%) with increased alveolar size and/or recruitment. Futier et al. (2011) explained that an increase in the ventilated lung areas, as evidenced by reaeration with alveolar recruitment decreased dead space variables. An increase in these variables would have been expected if no recruitment had occurred. Futier et al. (2011) identified that other limitations included a possibility of bias related to study investigators. The investigation period was also short and times of measurements were limited. Measurements were taken only during the first minutes after the initiation of mechanical ventilation, the sustained improvement was not studied.

\section{Cross Study Analysis}

A cross-study analysis was completed utilizing the CASP checklist (Appendix C). The cross-study analysis evaluates the similarities and differences between studies. All of the studies included in this systematic review provided results that were significant to the scope of this review. All of the studies offer transparency to the reader and provide appropriately cited recommendations. The most significant study and results in this 
systematic review are from the Talab et al. (2009) study. It had the largest sample size, as well as the most comprehensive methods for examining the prevention of atelectasis in the obese population undergoing an abdominal surgical procedure.

The Futier et al. (2011) study evaluated the addition of positive pressure and positive pressure with recruitment compared to conventional preoxygenation with spontaneous breaths at the induction of general anesthesia. The formation of atelectasis was not specifically measured; however, end-expiratory lung volumes were. Part of the aim of the Futier et al. (2011) study was to determine whether the noninvasive positive pressure ventilation would increase end-expiratory lung volumes compared with conventional spontaneous breathing ventilation. End-expiratory lung volumes would be increased by recruiting collapsed alveoli and, in turn, improve arterial oxygenation (Futier et al., 2011). If atelectasis is defined as the partial or complete collapse of lung tissue (Bendixen et al., 1964), then increasing end-expiratory lung volume suggests a decrease in atelectasis. Strandberg et al. (1986) found that atelectasis developed in $90 \%$ of patients after induction of general anesthesia. The Futier et al. (2011) study determined that positive pressure ventilation and positive pressure ventilation with recruitment was effective in improving oxygenation and expanding collapsed alveoli after the initiation of mechanical ventilation.

All five studies measured the effects of adding a recruitment maneuver to positive end-expiratory pressure on arterial oxygenation and atelectasis development. The Whalen et al. (2006) and Taleb et al. (2009) studies included post-operative outcomes. Taleb et al. (2009) and Reinius et al. (2009) utilized computed tomography scans in their studies to assess atelectasis development. Reinius et al. (2009) and Taleb et al. (2009) showed that 
PEEP alone improved arterial oxygenation compared to no positive pressure or RM without the initiation of PEEP. However, these studies demonstrated a more considerable improvement in oxygenation and decrease in atelectasis with RM followed by PEEP. Taleb et al. (2009) evaluated RM without PEEP, RM with lower PEEP, and RM with higher PEEP and showed an improvement in oxygenation and decrease in atelectasis with RM and higher PEEP. Futier et al. (2011) demonstrated that noninvasive positive pressure ventilation with RM improves oxygenation and end-expiratory lung volumes after the induction of anesthesia. Whalen et al. (2006) showed improvement in oxygenation and respiratory mechanics when a RM and increased PEEP was utilized compared to PEEP alone. Chalhoub et al. (2007) concluded that PEEP alone improves oxygenation and decreases atelectasis and the addition of a VCM further improves respiratory function. The studies that explored post-operative outcomes failed to demonstrate any improvement in post-operative outcomes with PEEP and RM despite the improvement in oxygenation and decrease in atelectasis. These studies utilized a small sample size at a single center and evaluated patients post-operatively for 24 hours. Further evaluation of post-operative outcomes and readmission rates would be beneficial.

The five studies covered in this systematic review all concluded that the use of a recruitment maneuver or vital capacity maneuver would improve arterial oxygenation and respiratory mechanics. However, one of the major limitations is that each study used a different definition of a recruitment maneuver or vital capacity maneuver. Specifically, the amount of PEEP, the pressure used for VCM or time for VCM varied significantly across studies. Whalen et al. (2006) defined their recruitment maneuver to maintain a tidal volume of $8 \mathrm{~mL} / \mathrm{kg}$ of ideal body weight, inspiratory: expiratory ratio of $1: 2$ and a 
perpetual increase in PEEP. PEEP was maintained throughout the procedure at $4 \mathrm{cmH} 2 \mathrm{O}$ and was incrementally increased to $10 \mathrm{cmH} 2 \mathrm{O}$ for three breaths, $15 \mathrm{cmH} 2 \mathrm{O}$ for three breaths, and $20 \mathrm{cmH} 2 \mathrm{O}$ for ten breaths. The recruitment maneuver took approximately two minutes. Taleb et al. (2009) defined their vital capacity maneuver as an increase in end-expiratory pressure to $40 \mathrm{cmH} 2 \mathrm{O}$ for $7-8$ seconds. Chalhoub et al. (2007) used a vital capacity maneuver of $40 \mathrm{cmH} 2 \mathrm{O}$ for 15 seconds. Futier et al. (2011) defined their recruitment maneuver as an increase in end-expiratory pressure to $40 \mathrm{cmH} 2 \mathrm{O}$ for 40 seconds. Reinius et al. (2009) performed a recruitment maneuver described as $55 \mathrm{cmH} 2 \mathrm{O}$ maintained for 10 seconds. Taleb et al. (2009), Chalhoub et al. (2007), and Futier et al. (2011) performed their recruitment of alveoli at the same pressure, but for a different length of time. Whalen et al. (2006) enforced a different type of recruitment altogether and Reinius et al. (2009) managed recruitment with the highest pressure of all the studies. Next, summary and conclusions will be presented. 


\section{Summary and Conclusions}

A systematic review was conducted to determine how alveolar recruitment maneuvers affect the formation of atelectasis in obese patients undergoing abdominal surgery. A literature review was conducted using PubMed, Medline, and CINHAL. The literature review focused on keywords such as obesity, atelectasis, postoperative complications, PEEP, recruitment maneuvers, and abdominal surgery. After inclusion and exclusion criteria were established and utilizing the PRISMA flowchart (Figure 1), five studies were identified and included in this systematic review. Data collection tables were created to identify the essential and pertinent variables for each study. Each study was critically appraised and analyzed using the Critical Appraisal Skills Programme (CASP) tool. The CASP tool assisted in determining the validity of each study, and the meaning and usefulness of the results. A cross-study analysis was completed by using the cross-study analysis template (Table 4), and was necessary to understand the scope of the study, review the author's intentions and recommendations following the results, and to quickly evaluate, compare and contrast the five studies.

After critically appraising and analyzing the studies, those that provided the most relevant data for this systematic review were Whalen et al. (2006), Talab et al. (2009), and Reinius et al. (2009). These studies had the most comprehensive methods and data collection procedures; however, the sample sizes were small and they were single-center studies. Chalhoub et al. (2006) and Futier et al. (2011) focused on arterial oxygenation and respiratory mechanics and did not include post-operative measurements. Although these studies did not include post-operative measurements, they provided essential information relevant to this systematic review. 
Each study focused on utilizing recruitment maneuvers and positive endexpiratory pressure to improve oxygenation and decrease the formation of atelectasis. Each study, however, used a different amount of pressure. The Whalen et al. (2006) study used $4 \mathrm{cmH} 2 \mathrm{O}$ of PEEP in one group and $12 \mathrm{cmH} 2 \mathrm{O}$ after recruitment in the other group. Taleb et al. (2009) studied recruitment with zero end-expiratory pressure, recruitment with $5 \mathrm{cmH} 2 \mathrm{O}$, and recruitment with $10 \mathrm{cmH} 2 \mathrm{O}$. Chalhoub et al. (2007) evaluated the effects of $8 \mathrm{mmHg}$ of PEEP with and without recruitment. Futier et al. (2011) studied ventilation without positive pressure, with positive pressure of $6-8 \mathrm{cmH} 2 \mathrm{O}$ and positive pressure of 6-8 $\mathrm{cmH} 2 \mathrm{O}$ and recruitment. Reinius et al. (2009) compared ventilation with $10 \mathrm{cmH} 2 \mathrm{O}$ of PEEP, PEEP of $10 \mathrm{cmH} 2 \mathrm{O}$ with recruitment and zero positive endexpiratory pressure with recruitment. The conclusion of each study found that recruitment with positive end-expiratory pressure was more effective than recruitment or PEEP alone at improving oxygenation. However, a consistent pressure has not been well defined for the obese population and further evaluation is necessary. It appears that a range of pressures, rather than one specific pressure, may be beneficial based on a patient's hemodynamic tolerance of adding positive end-expiratory pressure and recruitment to their ventilation regimen.

Each of the studies had a different definition of a recruitment maneuver or vital capacity maneuver. More specifically, the amount of pressure applied and the length of time it was applied varied across the studies. Reinius et al. (2009) concluded that a recruitment maneuver without positive end-expiratory pressure utilized after the maneuver and PEEP alone did not improve $\mathrm{PaO} 2 / \mathrm{FiO} 2$. This conclusion contradicts what Chalhoub et al. (2007) suggest, that PEEP does enhance arterial oxygenation and that 
adding a vital capacity maneuver further improves arterial oxygenation. This discrepancy may be related to the small sample size of the studies. Chalhoub et al. (2007) mention that their study was performed on patients receiving open bariatric surgery. Reinius et al. (2009) conducted their study on patients receiving gastric bypass surgery; however, does not mention if the operations were open or laparoscopic. Factors associated with laparoscopic surgery, such as positioning and the initiation of pneumoperitoneum, can have an effect on respiratory mechanics. Rothen et al. (1993) conducted a study to estimate the amount of atelectasis re-expanded by different lung volumes in healthy anesthetized patients. Rothen et al. (1993) utilized CT scans to assess atelectasis formation and re-expansion. They found that re-expansion of atelectatic lung tissue was accomplished by utilizing a vital capacity maneuver of a pressure of $40 \mathrm{cmH} 2 \mathrm{O}$ maintained for 15 seconds (Rothen et al., 1993). This pressure is equivalent to inflation to vital capacity; however, it may cause adverse cardiovascular effects (Rothen et al., 1993). Rothen et al. (1999) conducted another study that found a vital capacity maneuver maintained for 7-8 seconds, instead of 15 , would have less adverse cardiovascular effects and still re-expanded atelectatic lung tissue. Both of the studies by Rothen et al. (1993) and (1999) had very small sample sizes; however, 16 and 12, respectively. The studies included in this systematic review all found recruitment maneuvers with the addition of PEEP had favorable results. They are suggesting that an increase in positive endexpiratory pressure will help to re-expand collapsed lung tissue. However, a consistent pressure, volume, and length of time have not been well defined and further evaluation is needed. 
The limitations of this systematic review include the number of studies available that met the inclusion criteria. Only five studies were appropriate, and these studies all had small sample sizes and were limited to a single-center.

In summary, findings from the systematic review suggest a recruitment maneuver with positive end-expiratory pressure will increase oxygenation, improve gas exchange, and respiratory mechanics and prevent the formation of atelectasis.

Next, the recommendations and implications for advanced nursing practice will be presented. 


\section{Recommendations and Implications for Advanced Nursing Practice}

General anesthesia puts patients at increased risk of developing atelectasis and further pulmonary complications postoperatively. Up to $18 \%$ of obese patients undergoing surgery will develop postoperative pulmonary complications (Ball et al. 2018). Atelectasis can contribute to the development of complications post-operatively. An additional risk is associated with the obese population. Obesity increases the risk of developing atelectasis and dysfunctional respiratory mechanics during general anesthesia (Pepin et al., 2016). Post-operative pulmonary complications increase morbidity and mortality, prolong hospital stays, increase the cost of hospitalization, and requires extra hospital resources.

Anesthesia providers are at the forefront of preventing ventilation and perfusion mismatch while caring for patients in the operating room and beyond. Preventing postoperative complications is paramount to the plan of care of the Certified Registered Nurse Anesthetist (CRNA). Utilizing positive end-expiratory pressure and recruitment maneuvers throughout abdominal surgery on obese patients can help to prevent the development of atelectasis and maintain optimized respiratory mechanics and oxygenation. Recruitment maneuvers and PEEP are an easy and effective procedure to assist the anesthesia provider in maintaining arterial oxygenation and respiratory mechanics. CRNAs are in a prominent position to advocate for using recruitment maneuvers in patient care, especially with the obese population. By educating anesthesia providers, this review will support the anesthesia care team to implement best practices that will lead to improved patient outcomes, reduced morbidity and reduced hospital 
costs associated with post-operative complications associated with intraoperative respiratory management.

Further research is necessary to confirm the results reported in this systematic review. Research should focus on whether the addition of recruitment maneuvers decreases post-operative pulmonary complications, morbidity, mortality, and any adverse outcomes. A large, multicenter, multi-continent study would be preferable. Due to the detrimental effects of the induction of anesthesia on all patients receiving anesthesia, and inconsistencies in levels of PEEP and recruitment maneuvers, more research is necessary to determine optimal levels of PEEP and recruitment. Additionally, more research is needed to determine the post-operative effects of atelectasis on overall morbidity and mortality in all populations.

The American Association of Nurse Anesthetists (AANA) offers a variety of resources to assist the practitioner in employing evidence-based practices to their care plan. The AANA publishes guidelines to facilitate effective, efficient, and safe care. Currently, there are no guidelines on utilizing positive end-expiratory pressure or recruitment maneuvers in the operating room. Future research can support the development of guidelines to promote standardization of practices in the use of PEEP and recruitment intraoperatively. CRNAs are in a critical position to advocate for utilizing evidence-based practices in their anesthetic plan and providing and educating other providers to incorporate these practices into their plan. It is imperative that the CRNA continue to implement innovative practices in their care, remain current with research, and new treatment methods. 


\section{References}

Acosta, P., Santisbon, E., \& Varon, J. (2007). The use of positive end-expiratory pressure in mechanical ventilation. Critical Care Clinics, 23(2), 251-61. doi: 10.1016 /j.ccc.2006.12.012.

Aldenkortt, M., Lysakowski, C., Elia, N., Brochard, L., \& Tramer, M. R. (2012). Ventilation strategies in obese patients undergoing surgery: A quantitative systematic review and meta-analysis. British Journal of Anaesthesia, 109(4), 493502.

Almarakbi, W.A., Fawzi, H.M., \& Alhashemi, J.A. (2009). Effects of four intraoperative ventilatory strategies on respiratory compliance and gas exchange during laparoscopic gastric banding in obese patients. British Journal of Anaesthesia, 102(6), 862-868. doi:10.1093/bja/aep084.

Ball, L., Hemmes, S.N.T., Serpa Neto, A., Bluth, T., Canet, J., Hiesmayr, M...Pelosi, P. (2018). Intraoperative ventilation settings and their associations with postoperative pulmonary complications in obese patients. British Journal of Anaesthesia. 121(4). 899-908.

Bartlett D. (1971). Origin and regulation of spontaneous deep breaths. Respiratory Physiololgy, 12(2), 230-238.

Bendixen H., Smith G., \& Mead J. (1964). Pattern of ventilation in young adults. Journal of Applied Physiology, 19, 195-98.

Bluth, T., Teichmann, R., Kiss, T., Bobek, I., Canet, J., Cinnella, G...Gama de Abreau, M. (2017). Protective intraoperative ventilation with higher versus lower levels of 
positive end expiratory pressure in obese patients (PROBESE): study protocol for a randomized control trial. Trials, 18(202), 1-22. doi:10.1186/s13063-017-1929-0.

Chalhoub, V., Yazigi, A., Sleilaty, G., Haddad, F., Noun, R., Madi-Jebara, S., \& Yazbeck, P. (2007). Effect of vital capacity manoeuvres on arterial oxygenation in morbidly obese patients undergoing open bariatric surgery. European Journal of Anaesthesiology, 24, 283-288.

Center for Disease Control and Prevention. (2016). Defining adult overweight and obesity. Retrieved from: https://www.cdc.gov/obesity/adult/defining.html. Coussa, M., Proietti, S., Schnyder, P., Frascarolo, P., Suter, M., Spahn, D.R., \& Magnusson, L., (2004). Prevention of atelectasis formation during the induction of general anesthesia in morbidly obese patients. Anesthesia \& Analgesia, 98, 1491-1495.

Critical Appraisal Skills Programme. (2017). CASP systematic review checklist. Retrieved from: http://www.casp-uk.net/criticalappraisal.

Futier, E., Constantin, J.M., Pelosi, P., Chanques, G., Massone, A., Petit, A.,...Jaber, S. (2011). Noninvasive ventilation and alveolar recruitment maneuver improve respiratory function during and after intubation of morbidly obese patients. A randomized controlled study. Anesthesiology, 114, 1354-1363.

Hall, J. E. (2016). Guyton and Hall textbook of medical physiology (13 ${ }^{\text {th }}$ edition). Philadelphia, PA: Elsevier.

Hartland, B.L., Newell, T.J. \& Damico, N. (2014). Alveolar recruitment maneuvers: Are your patients missing out? AANA Journal, 82(4), 307-319. 
Hedenstierna, G., \& Rothen, H. (2000). Atelectasis formation during anesthesia: causes and measures to prevent it. J Clin Monit Comput, 16(5-6), 329-335.

Hodgson, L.E., Murphy, P.B. \& Hart, N. (2015). Respiratory management of the obese patient undergoing surgery. Journal of Thoracic Disease, 7(5), 943 - 952.

Jaber, S., Coisel, Y., Chanques, G., Futier, E., Constantin, J.M., Michelet, P.,... Marret, E. (2012). A multicentre observational study of intra-operative ventilatory management during general anaesthesia: tidal volumes and relation to body weight. The Association of Anaesthetists of Great Britain and Ireland, 67, 9991008.

Miller, R.D. (2015). Miller's anesthesia ( $8^{\text {th }}$ edition). Philadelphia, PA: Elsevier.

Moher, D., Liberati, A., Tetzlaff, J., \& Altman, D. (2009). Preferred reporting items for systematic reviews and meta-analyses: The PRISMA statement. Annals of Internal Medicine, 151(4), 264-270.

Nepogodiev, D., Chapman, S.J., Glasbey, J., Kelly, M., Kahtri, C., Drake, T.M.,...Banghu, A.(2015). Determining surgical complications in the overweight (DISCOVER): a multicenter observational cohort study to evaluate the role of obesity as a risk factor for postoperative complications in general surgery. $B M J$ Open, 5, 1-8.

Neligan, P (2012). Postoperative noninvasive ventilation. Anesthesiology Clinics, 30(3), 495-511. doi:10.1016/j.anclin.2012.07.002

Pepin, J.L., Timsit, J.F., Tamisier, R., Borel, J.C., Levy, P., \& Jaber, S. (2016). Prevention and care of respiratory failure in obese patients. Lancet Respir Med, 4(5), 407-418. 
Qaseem, A., Snow, V., Fitterman, N., Hornbake, R., Lawrence, V., Smetana, G.,... Owens, D. (2006). Risk assessment for and strategies to reduce perioperative pulmonary complications for patients undergoing noncardiothoracic surgery: A guideline from the American College of Physicians. Annals of Internal Medicine, 144(8), 575-581.

Reinius, H., Jonsson, L., Gustafsson, S., Sundbom, M., Duvernoy, O., Pelosi, P.,...Freden, F (2009). Prevention of atelectasis in morbidly obese patients during general anesthesia and paralysis. Anesthesiology, 111(5), 979-987.

Rothen, H.U., Sporre, B., Engberg, G., Wegenius, G. \& Hedenstierna, G. (1993). Reexpansion of atelectasis during general anaesthesia: A computed tomography study. British Journal of Anaesthesia, 71, 788-795.

Rothen, H.U., Neumann, P., Berglund, J.E., Valtysson, J., Magnusson, A., \& Hedenstierna, G. (1999). Dynamics of re-expansion of atelectasis during general anaesthesia. British Journal of Anaesthesia. 82, 551-556.

Rusca, M., Proietti, S., Schnyder, P., Frascarolo, P., Hedenstierna, G., Spahn, D. \& Magnusson, L. (2003). Prevention of atelectasis formation during induction of general anesthesia. Anesth Analg, 97, 1835-1839. doi:

10.1213/01.ANE.0000087042.02266.F6.

Strandberg, A., Tokics, L., Brismar, B., Lundquist, H. \& Hedenstierna, G. (1986). Atelectasis during anaesthesia and in the postoperative period. Acta Anaesthesiologica Scandinavica, 30(2), 154-158.

Talab, H. F., Zabani, I. A., Abdelrahman, H. S., Bukhari, W. L., Mamoun, I., Ashour, M. A.,...El Sayed, S. I. (2009). Intraoperative ventilatory strategies for prevention of 
pulmonary atelectasis in obese patients undergoing laparoscopic bariatric surgery. Anesthesia \& Analgesia, 109(5), 1511-1519.

Whalen, F.X., Gajic, O., Thompson, G.B., Kendrick, M.L., Que, F.L., Williams, B.A.,...Sprung, J. (2006). The effects of the alveolar recruitment maneuver and positive end-expiratory pressure on arterial oxygenation during laparoscopic bariatric surgery. Anesthesia \& Analgesia, 102, 298-305.

Whitlock, G., Lewington, S., Sherliker, P., Clarke, R., Emberson, J., Halsey, J.,...Peto, R. (2009). Body-mass index and cause-specific mortality in 900,000 adults: collaborative analyses of 57 prospective studies. Lancet, 373, 1083-1096. 
Appendix A

Results in Data Collection Table 


\begin{tabular}{|c|c|}
\hline Study title & $\begin{array}{l}\text { The effects of the alveolar recruitment maneuver and positive end- } \\
\text { expiratory pressure (PEEP) on arterial oxygenation during laparoscopic } \\
\text { bariatric surgery }\end{array}$ \\
\hline $\begin{array}{l}\text { Study reference } \\
\text { citation }\end{array}$ & $\begin{array}{l}\text { Whalen, F.X., Gajic, O., Thompson, G.B., Kendrick, M.L., Que, F.L., } \\
\text { Williams, } \\
\text { B.A.,...Sprung, J. (2006). The effects of the alveolar recruitment maneuver } \\
\text { and positive end-expiratory pressure on arterial oxygenation during } \\
\text { laparoscopic bariatric surgery. Anesthesia \& Analgesia, 102, 298-305. }\end{array}$ \\
\hline Population & $\begin{array}{l}20 \text { morbidly obese adult patients between } 25-65 \text { years old with BMI }>40 \\
\mathrm{~kg} / \mathrm{m}^{2}\end{array}$ \\
\hline Intervention & $\begin{array}{l}2 \text { groups: } \\
\text { Control group }(\mathrm{n}=10)-\text { No recruitment maneuver utilized, PEEP was } \\
\text { maintained at } 4 \mathrm{cmH} \mathrm{H}_{2} \mathrm{O} \text { throughout. } \\
\text { Recruitment group }(\mathrm{n}=10)-\mathrm{In} \text { a stepwise fashion, } 3 \text { breaths at } 10 \mathrm{cmH}_{2} \mathrm{O} \text {, } \\
\text { then to } 15 \mathrm{cmH}_{2} \mathrm{O}(3 \text { breaths }) \text {, and finally } 20 \mathrm{cmH}_{2} \mathrm{O} \text { ( } 10 \text { breaths). After the } \\
\text { recruitment maneuver, PEEP was set at } 12 \mathrm{cmH}_{2} \mathrm{O}\end{array}$ \\
\hline Comparisons & PEEP alone versus PEEP with a recruitment maneuver \\
\hline Aim of Study & $\begin{array}{l}\text { To assess how recruitment maneuvers (RM) and positive end-expiratory } \\
\text { pressure (PEEP) effect respiratory mechanics, hemodynamics and } \\
\text { oxygenation. }\end{array}$ \\
\hline Inclusion criteria & ASA class 2 or $3,25-65$ years old, BMI $>40 \mathrm{~kg} / \mathrm{m}^{2}$ \\
\hline Exclusion criteria & $\begin{array}{l}\text { Age below } 25 \text { and above } 65 \text {, significant preoperative pulmonary disease } \\
\text { (forced expiratory volume in one second }<50 \% \text { of predicted and forced } \\
\text { vital capacity }<50 \% \text { of predicted), active asthma, receiving home oxygen } \\
\text { therapy. }\end{array}$ \\
\hline Outcome measure & $\begin{array}{l}\text { "The ratio of arterial oxygen partial pressure to inspiratory oxygen } \\
\text { concentration }\left(\mathrm{PaO}_{2} / \mathrm{FIO}_{2}\right) \text {, and other variables related to gas exchange, } \\
\text { oxygenation, ventilation, respiratory mechanics, and hemodynamics are } \\
\text { reported separately for patients randomized to recruitment maneuver and } \\
\text { control...Differences in these variables across procedure groups over time } \\
\text { up to the end of surgery were tested using repeated-measures analysis of } \\
\text { variance models. Age, sex, BMI, and baseline value of the variable were } \\
\text { included as adjustor variables in all models. A procedure by time } \\
\text { interaction was tested to determine if the nature of the treatment effect } \\
\text { differed over time." (Whalen et al., 2006) Medical records and clinical } \\
\text { notes were reviewed after hospital discharge for postoperative pulmonary } \\
\text { complications such as: pulmonary embolism, respiratory failure, } \\
\text { pneumonia, clinical pulmonary infection score }>6 \text {, or new onset of fever } \\
\text { and infiltrates associated with leukocytosis/leukopenia, purulent sputum or } \\
\text { positive sputum culture, atelectasis requiring intervention and length of } \\
\text { hospitalization. }\end{array}$ \\
\hline Significance & $\begin{array}{l}\text { For obese patients undergoing laparoscopic bariatric surgery, recruitment } \\
\text { maneuvers followed by PEEP was effective in increasing perioperative } \\
\mathrm{PaO}_{2} \text {. The improvement was maintained, however, the effect disappeared } \\
\text { within } 30 \text { minutes of extubation. While the recruitment group sustained } \\
\text { better } \mathrm{PaO}_{2} \text { values intraoperatively }(\mathrm{p}<0.01) \text {, presumably due to decreased } \\
\text { atelectasis, there was no significant difference in postoperative } \\
\text { complications between the groups. }\end{array}$ \\
\hline
\end{tabular}




\begin{tabular}{|c|c|}
\hline Study title & $\begin{array}{l}\text { Effect of vital capacity manoeuvres on arterial oxygenation in morbidly } \\
\text { obese patients undergoing open bariatric surgery. }\end{array}$ \\
\hline $\begin{array}{l}\text { Study reference } \\
\text { citation }\end{array}$ & $\begin{array}{l}\text { Chalhoub, V., Yazigi, A., Sleilaty, G., Haddad, F., Noun, R., Madi-Jebara, } \\
\text { S., Yazbeck, P. (2007). Effect of vital capacity manoeuvres on arterial } \\
\text { oxygenation in morbidly obese patients undergoing open bariatric surgery. } \\
\text { European Journal of Anaesthesiology, 24, 283-288. }\end{array}$ \\
\hline Population & 52 adult obese patients with $\mathrm{BMI}>40 \mathrm{~kg} / \mathrm{m}^{2}$ \\
\hline Intervention & $\begin{array}{l}2 \text { groups: } \\
\text { Group } 1(\mathrm{n}=26) \text { : PEEP of } 8 \mathrm{mmHg} \text { was added to ventilation regimen } \\
\text { Group } 2(\mathrm{n}=26) \text { : a vital capacity maneuver (VCM) was applied before } \\
\text { adding PEEP of } 8 \mathrm{mmHg} \text { to ventilation regimen. (VCM performed by } \\
\text { inflating the lungs to peak airway pressure of } 40 \mathrm{cmH}_{2} \mathrm{O} \text { and maintaining } \\
\text { this pressure for } 15 \mathrm{~s})\end{array}$ \\
\hline Comparisons & Positive end-expiratory pressure and a recruitment maneuver \\
\hline Aim of Study & $\begin{array}{l}\text { To assess the effects of PEEP, immediately after vital capacity maneuvers, } \\
\text { on arterial oxygenation in morbidly obese patients undergoing open } \\
\text { bariatric surgery. }\end{array}$ \\
\hline Inclusion criteria & $\begin{array}{l}\text { Morbidly obese adult patients }\left(>40 \mathrm{~kg} / \mathrm{m}^{2}\right), \text { ASA } 3 \text {, undergoing open } \\
\text { bariatric surgery }\end{array}$ \\
\hline Exclusion criteria & $\begin{array}{l}\text { Cardiac, pulmonary and neurological diseases were considered for } \\
\text { exclusion }\end{array}$ \\
\hline Outcome measure & $\begin{array}{l}\text { - Arterial blood gases, end tidal carbon dioxide, peak airway } \\
\text { pressure, expired tidal volume, respiratory rate, mean arterial } \\
\text { pressure and heart rate were measured in the two groups at different } \\
\text { times: } \\
\text { T0: before the application of VCM and/or PEEP } \\
\text { T1: } 10 \text { minutes after the application of VCM and/or PEEP } \\
\text { T2: at the end of surgery before abdominal closure } \\
\text { - } \mathrm{PaO}_{2} \text { and } \mathrm{SaO}_{2} \text { were measured and alveolar-arterial oxygen pressure } \\
\text { gradient was calculated }\left(\mathrm{A}-\mathrm{aDO}_{2}\right)\end{array}$ \\
\hline Significance & $\begin{array}{l}\text { The two groups were comparable in age, sex, BMI, surgical time, time } \\
\text { interval between T1 and T2, intraoperative total fluid administration, urine } \\
\text { output, extubation time and length of stay in the PACU. } \\
\text { - } \mathrm{A}-\mathrm{aDO}_{2} \text { was decreased at } \mathrm{T} 2 \text { as compared to } \mathrm{T} 0 \text { and } \mathrm{T} 1 \text { in Group } 1 \\
(\mathrm{P}<0.001) \\
\text { - } \mathrm{A}-\mathrm{aDO}_{2} \text { was decreased at } \mathrm{T} 1 \text { and } \mathrm{T} 2 \text { as compared to T0 in Group } 2 \\
(\mathrm{P}<0.001) \\
\text { - Arterial oxygenation parameters at } \mathrm{T} 1 \text { and } \mathrm{T} 2 \text { were significantly } \\
\text { improved in Group } 2 \text { compared to Group } 1(\mathrm{P}<0.001)\end{array}$ \\
\hline
\end{tabular}


The application of a VCM significantly supplemented the beneficial effects of PEEP. The VCM overcame the opening pressure of the collapsed alveoli and recruited atelectatic areas. 


\begin{tabular}{|c|c|}
\hline Study title & $\begin{array}{l}\text { Intraoperative ventilatory strategies for prevention of pulmonary atelectasis } \\
\text { in obese patients undergoing laparoscopic bariatric surgery }\end{array}$ \\
\hline $\begin{array}{l}\text { Study reference } \\
\text { citation }\end{array}$ & $\begin{array}{l}\text { Talab, H. F., Zabani, I. A., Abdelrahman, H. S., Bukhari, W. L., Mamoun, } \\
\text { I., Ashour, M. A.,... } \\
\text { El Sayed, S. I. (2009). Intraoperative ventilatory strategies for prevention } \\
\text { of } \\
\text { pulmonary atelectasis in obese patients undergoing laparoscopic bariatric } \\
\text { surgery. Anesthesia \& Analgesia, 109(5), 1511-1519. }\end{array}$ \\
\hline Population & $\begin{array}{l}66 \text { adult obese patients between ages } 20 \text { and } 50 \text { years old, with BMI } \\
\text { between } 30 \text { and } 50 \mathrm{~kg} / \mathrm{m}^{2}\end{array}$ \\
\hline Intervention & 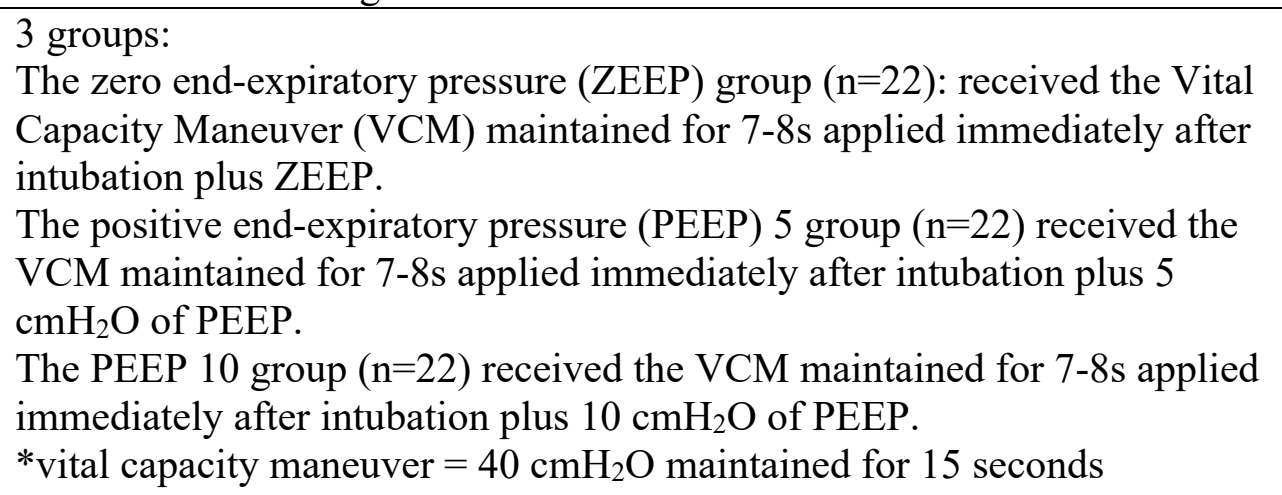 \\
\hline Comparisons & $\begin{array}{l}0 \text { PEEP with VCM, } 5 \mathrm{cmH}_{2} \mathrm{O} \text { PEEP with VCM, } 10 \mathrm{cmH}_{2} \mathrm{O} \text { PEEP with } \\
\text { VCM }\end{array}$ \\
\hline Aim of Study & $\begin{array}{l}\text { To evaluate strategies to prevent the formation of atelectasis in obese } \\
\text { patients undergoing laparoscopic bariatric surgeries. To evaluate the safety } \\
\text { and efficacy of the vital capacity maneuver (VCM), followed by different } \\
\text { levels of PEEP, used to prevent postoperative lung atelectasis in obese } \\
\text { patients undergoing laparoscopic bariatric surgery. } \\
\text { *vital capacity maneuver = recruitment maneuver }\end{array}$ \\
\hline Inclusion criteria & $\begin{array}{l}\text { Adults between the ages of } 20 \text { and } 50 \text { years old, with a BMI between } 30 \\
\text { and } 50 \mathrm{~kg} / \mathrm{m}^{2} \text {, undergoing laparoscopic bariatric surgery. }\end{array}$ \\
\hline Exclusion criteria & $\begin{array}{l}\text { Hospitalization for more than } 24 \text { hours before surgery, history of heart or } \\
\text { lung diseases, any clinical signs of cardiopulmonary disease during } \\
\text { preoperative physical exam (jugular venous distention, gallop rhythm, } \\
\text { hepatomegaly, tibial edema, or rales on auscultation of the chest, or any } \\
\text { abnormalities in the preoperative } 12 \text {-lead electrocardiogram or chest } \\
\text { radiograph). Any complications that required laparotomy. }\end{array}$ \\
\hline
\end{tabular}




\begin{tabular}{|c|c|}
\hline Outcome measure & $\begin{array}{l}\text { - Heart rate, MAP (noninvasive) and arterial oxygen saturation were } \\
\text { measure at the following times: } \\
\text { T0: before induction of anesthesia, breathing room air } \\
\text { T1: immediately after induction of anesthesia } \\
\text { T2: immediately after VCM } \\
\text { T3: immediately after establishing pneumoperitoneum } \\
\text { T4: immediately after patient positioning (modified lithotomy position with } \\
\text { anti-Trendelenburg } \\
\text { T5: } 30 \text { min. after establishing positioning } \\
\text { T6: } 60 \text { min. after establishing positioning/end of procedure } \\
\text { T7: immediately after PACU admission } \\
\text { T8: before discharge from PACU } \\
\text { - ABGs were obtained pre- and post-operatively to measure } \mathrm{PaO}_{2} \text { and } \\
\quad \text { to calculate alveolar-arterial PaO } \mathrm{O}_{2} \text { gradient }(\mathrm{A}-\mathrm{a} \text { PaO } \\
\text { C) }\end{array}$ \\
\hline Significance & $\begin{array}{l}\text { There were no statistically significant differences in regards to age, sex, } \\
\text { ASA, physical classification, duration of surgery or BMI between the } 3 \\
\text { groups. There were also no statistically significant differences in MAP and } \\
\text { heart rate intraoperatively. } \\
\text { - There was a significant decrease in postoperative A-a gradient in } \\
\text { the PEEP } 10 \text { group }(\mathrm{P}<0.05) \\
\text { - Time spent in PACU was significantly shorter in the PEEP } 10 \\
\text { group (P<0.05) } \\
\text { - Less patients in the PEEP } 10 \text { group needed oxygen supplementation } \\
\text { (P<0.05) } \\
\text { No significant desaturation, chest infection or bronchospasm was } \\
\text { observed in the PEEP } 10 \text { group during the first } 48 \text { hours } \\
\text { postoperatively (compared with } 4 \text { patients in the ZEEP group and } 3 \\
\text { patients in the PEEP } 5 \text { group) }(\mathrm{P}<0.05) \\
\text { Patients in the PEEP } 10 \text { group had significantly less atelectasis } \\
\text { postoperatively }(\mathrm{P}<0.05) \\
\text { Postoperative atelectasis was comparable between the ZEEP and } \\
\text { PEEP } 5 \text { groups }(\mathrm{P}<0.05)\end{array}$ \\
\hline
\end{tabular}




\begin{tabular}{|c|c|}
\hline Study title & $\begin{array}{l}\text { Prevention of atelectasis in morbidly obese patients during general } \\
\text { anesthesia and paralysis }\end{array}$ \\
\hline $\begin{array}{l}\text { Study reference } \\
\text { citation }\end{array}$ & $\begin{array}{l}\text { Reinius, H., Jonsson, L., Gustafsson, S., Sundbom, M., Duvernoy, O., } \\
\text { Pelosi, P.,...Freden, F } \\
\text { (2009). Prevention of atelectasis in morbidly obese patients during general } \\
\text { anesthesia and paralysis. Anesthesiology, } 111(5), 979-987 .\end{array}$ \\
\hline Population & 30 adult patients between ages 25 and 54 years old with a BMI $>40 \mathrm{~kg} / \mathrm{m}^{2}$ \\
\hline Intervention & $\begin{array}{l}\text { Positive end-expiratory pressure, zero end-expiratory pressure and a } \\
\text { recruitment maneuver }\end{array}$ \\
\hline Comparisons & $\begin{array}{l}3 \text { groups: } \\
\text { Group 1: received positive end-expiratory pressure }(\mathrm{PEEP}) \text { of } 10 \mathrm{cmH}_{2} \mathrm{O} \\
\text { Group 2: received recruitment maneuver }(\mathrm{RM})+\text { zero end-expiratory } \\
\text { pressure }(\mathrm{ZEEP})(\mathrm{RM} \text { followed by ZEEP) } \\
\left.\text { Group 3: RM+PEEP (RM followed by PEEP of } 10 \mathrm{cmH}_{2} \mathrm{O}\right) \\
\text { *The recruitment maneuver was performed by increasing the inspiratory } \\
\text { pressure manually to } 55 \mathrm{cmH}_{2} \mathrm{O} \text { and held for } 10 \text { seconds }\end{array}$ \\
\hline Aim of Study & $\begin{array}{l}\text { To assess whether a recruitment maneuver followed by PEEP would be the } \\
\text { most efficient way to improve respiratory function by reducing atelectasis } \\
\text { in morbidly obese patients during general anesthesia and paralysis in the } \\
\text { supine position. }\end{array}$ \\
\hline Inclusion criteria & $\begin{array}{l}\text { Between the ages of } 25 \text { and } 54 \text { years old, BMI }>40 \mathrm{~kg} / \mathrm{m}^{2}, \text { ASA } 2-3, \\
\text { schedule for elective gastric bypass surgery en-Roux }\end{array}$ \\
\hline Exclusion criteria & $\begin{array}{l}\text { Younger than } 18 \text { years of age, pregnancy, cardiac disease (hx of ischemic } \\
\text { heart disease and NYHA class III or IV), obstructive pulmonary disease } \\
\text { (forced expiratory volume below } 80 \% \text { of expected value) }\end{array}$ \\
\hline Outcome measure & $\begin{array}{l}\text { Computed Tomography was obtained before anesthesia, } 5 \text { minutes after } \\
\text { induction and tracheal intubation, and } 5 \mathrm{~min}, 20 \mathrm{~min} \text { and } 40 \text { minutes after } \\
\text { intervention }\end{array}$ \\
\hline Significance & $\begin{array}{l}\text { There was no significant difference in hemodynamics, oxygenation and } \\
\text { respiratory compliance between the } 3 \text { groups. Induction of anesthesia and } \\
\text { paralysis was accompanied by approximately } 50 \% \text { reduction of end- } \\
\text { expiratory long volume (EELV), promoted atelectasis, and caused } \\
\text { significant fall in arterial oxygenation. (after intervention, EELV increased } \\
32 \% \text { in the PEEP group and } 64 \% \text { in the } \mathrm{RM}+\mathrm{PEEP} \text { group, no changes in } \\
\text { EELV were observed in the } \mathrm{RM}+\mathrm{ZEEP} \text { group) } \\
\text { - } \mathrm{Recruitment} \text { maneuver followed by PEEP caused an increase in } \\
\mathrm{PaO}_{2} / \mathrm{FiO} \text { ratio at } 5 \text { min. and was sustained (PEEP alone or } \\
\mathrm{RM}+\mathrm{ZEEP} \text { did not) }(\mathrm{P}<0.0001) \\
\text { - } \mathrm{RM}+\mathrm{PEEP} \text { increased the fractional amount of normally aerated } \\
\text { tissue and resulted in major reduction of nonaerated tissue. } \\
(\mathrm{P}<0.0001) \\
\text { - } \mathrm{RM}+\mathrm{PEEP} \text { effectively opens up atelectatic lung tissue and improves } \\
\text { oxygenation }(\mathrm{P}<0.0001) \\
\text { - } \mathrm{PEEP} \text { or } \mathrm{RM}+\mathrm{ZEEP} \text { was not effective in reaching sustained } \\
\text { improvement of respiratory function. }\end{array}$ \\
\hline
\end{tabular}




\begin{tabular}{|c|c|}
\hline Study title & $\begin{array}{l}\text { Noninvasive ventilation and alveolar recruitment maneuver improve } \\
\text { respiratory function during and after intubation of morbidly obese } \\
\text { patients }\end{array}$ \\
\hline $\begin{array}{l}\text { Study reference } \\
\text { citation }\end{array}$ & $\begin{array}{l}\text { Futier, E., Constantin, J.M., Paugam-Burtz, C., Pascal, J., Eurin, M., } \\
\text { Neuschwander, A., } \\
\text {...Jaber, S. (2011). A trial of intraoperative low-tidal-volume ventilation } \\
\text { in abdominal surgery. The New England Journal of Medicine, 369(5), } \\
\text { 428-437. }\end{array}$ \\
\hline Population & 70 adult patients with $\mathrm{BMI}>/=$ to $40 \mathrm{~kg} / \mathrm{m}^{2}$ \\
\hline Intervention & $\begin{array}{l}3 \text { groups: } \\
\text { Group } 1(\mathrm{n}=22) \text { : conventional preoxygenation with spontaneous } \\
\text { breathing via facemask } \\
\text { Group } 2(\mathrm{n}=22) \text { : noninvasive positive pressure ventilation (NPPV) } \\
\text { Group } 3(\mathrm{n}=22) \text { : NPPV with recruitment maneuver (after tracheal } \\
\text { intubation) } \\
\text { *NPPV and } \mathrm{NPPV}+\mathrm{RM} \text { groups: pressure support ventilation was } \\
\text { adjusted to maintain an expiratory tidal volume of } 8 \mathrm{ml} / \mathrm{kg} \text { of predicted } \\
\text { body weight, a PEEP level of } 6-8 \mathrm{cmH}_{2} \mathrm{O} \text { and airway pressure of less } \\
\text { than } 18 \mathrm{cmH} \mathrm{C}_{2} \mathrm{O} \\
{ }^{*} \mathrm{RM} \text { consisted of applying continuous positive airway pressure of } 40 \\
\mathrm{cmH}_{2} \mathrm{O} \text { for } 40 \text { seconds }\end{array}$ \\
\hline Comparisons & $\begin{array}{l}\text { Spontaneous breathing, noninvasive positive pressure ventilation and a } \\
\text { recruitment maneuver }\end{array}$ \\
\hline Aim of Study & $\begin{array}{l}\text { To determine whether noninvasive positive pressure ventilation } \\
\text { improves oxygenation and end-expiratory lung volume compared with } \\
\text { conventional preoxygenation at induction of anesthesia, and whether } \\
\text { recruitment maneuvers applied after noninvasive positive pressure } \\
\text { ventilation further improves respiratory function after initiation of } \\
\text { mechanical ventilation. }\end{array}$ \\
\hline Inclusion criteria & $\begin{array}{l}\text { Adult patients with ASA class } 2-3 \text { and BMI }>/=40 \mathrm{~kg} / \mathrm{m}^{2} \text { scheduled for } \\
\text { laparoscopic sleeve gastrectomy or Roux-en- } Y \text { gastric bypass }\end{array}$ \\
\hline Exclusion criteria & $\begin{array}{l}\text { Consent refusal, age younger than } 18 \text { years old, pregnancy, severe } \\
\text { cardiac failure (defined as New York Heart Association classification } \\
\text { greater than III), and chronic obstructive pulmonary disease (defined as } \\
\text { forced expiratory volume in } 1 \text { second less than } 80 \% \text { of expected value) }\end{array}$ \\
\hline Outcome measure & $\begin{array}{l}\text { Arterial blood samples were taken } 1-2 \text { minutes before and immediately } \\
\text { after the } 5 \text {-minute preoxygenation trial, immediately after intubation, } \\
\text { and } 5 \text { minutes after the onset of mechanical ventilation at a PEEP of } 10 \\
\mathrm{cmH}_{2} \mathrm{O} \text {. End-tidal oxygen concentration }\left(\mathrm{EtO}_{2}\right) \text {, end-tidal carbon } \\
\text { dioxide }\left(\mathrm{EtCO}_{2}\right) \text { and arterial to end-tidal partial pressure of carbon } \\
\text { dioxide }\left(\mathrm{Pa}-\mathrm{EtCO}_{2} \text {; a useful indicator of lung collapse and reopening }\right. \\
\text { that has been found to correlate closely with atelectatic lung area on } \mathrm{CT} \\
\text { scan) were recorded 5-minutes after mechanical ventilation. End- } \\
\text { Expiratory lung volumes were compared before and after intervention. }\end{array}$ \\
\hline
\end{tabular}




\begin{tabular}{|c|c|}
\hline Significance & $\begin{array}{l}\text { There were no significant differences in preoperative EELV, } \mathrm{PaO}_{2} \text {, } \\
\text { duration of anesthesia, and hemodynamics between the groups. } \\
\text { - Mean } \mathrm{EtO}_{2} \text { values were higher in the NPPV and NPPV }+\mathrm{RM} \\
\text { group }(\mathrm{P}<0.01) \\
\text { - After intubation, } \mathrm{PaO}_{2} \text { was significantly higher in the NPPV and } \\
\mathrm{NPPV}+\mathrm{RM} \text { group }(\mathrm{P}<0.001) \\
\text { - } \mathrm{PaO}_{2} \text { was further increased in the NPPV }+\mathrm{RM} \text { group }(\mathrm{P}<0.01) \\
\text { - End Expiratory Reserve Volume }(\mathrm{EELV}) \text { was significantly } \\
\text { higher in the NPPV and NPPV }+\mathrm{RM} \text { group }(\mathrm{P}<0.001) \\
\text { - } \mathrm{PaCO} \mathrm{O}_{2} \text { was significantly reduced after the recruitment maneuver } \\
\text { was applied }(\mathrm{P}=0.038)\end{array}$ \\
\hline
\end{tabular}


Appendix B

Cross-Study Analysis 


\begin{tabular}{|c|c|c|c|c|}
\hline Study/Year & Cohort & Aim & Groups & Evaluation \\
\hline $\begin{array}{l}\text { Whalen, et } \\
\text { al. } \\
\qquad \text { (2006) }\end{array}$ & $\begin{array}{c}20 \text { morbidly } \\
\text { obese } \\
\text { patients } \\
\text { between the } \\
\text { ages of } 25- \\
65 \text { years old } \\
\text { with a BMI } \\
>40 \mathrm{~kg} / \mathrm{m}^{\wedge} 2 \text {, } \\
\text { ASA class } 2 \\
\text { or } 3\end{array}$ & $\begin{array}{l}\text { To assess how } \\
\text { recruitment } \\
\text { maneuvers } \\
\text { (RM) and } \\
\text { positive end- } \\
\text { expiratory } \\
\text { pressure } \\
\text { (PEEP) effect } \\
\text { respiratory } \\
\text { mechanics, } \\
\text { hemodynamics } \\
\text { and } \\
\text { oxygenation. }\end{array}$ & $\begin{array}{c}\text { 1) No } \\
\text { recruitment } \\
\text { maneuver } \\
\text { utilized, PEEP } \\
\text { was maintained } \\
\text { at } 4 \mathrm{cmH}_{2} \mathrm{O} \\
\text { throughout. } \\
\text { 2) In a stepwise } \\
\text { fashion, } 3 \\
\text { breaths at } 10 \\
\text { cmH2O, then } \\
\text { to } 15 \mathrm{cmH} 2 \mathrm{O} \\
\text { (3 breaths), and } \\
\text { finally } 20 \\
\text { cmH2O (10 } \\
\text { breaths). After } \\
\text { the recruitment } \\
\text { maneuvers, } \\
\text { PEEP was set } \\
\text { at } 12 \text { cmH2O }\end{array}$ & $\begin{array}{l}\text { Positive End } \\
\text { Expiratory } \\
\text { Pressure with } \\
\text { recruitment } \\
\text { maneuvers } \\
\text { increased } \\
\text { arterial } \\
\text { oxygenation } \\
\text { and respiratory } \\
\text { mechanics. } \\
\text { There were no } \\
\text { differences in } \\
\text { post-operative } \\
\text { outcomes. }\end{array}$ \\
\hline $\begin{array}{l}\text { Taleb, et } \\
\text { al. } \\
(2009)\end{array}$ & $\begin{array}{c}66 \text { adult } \\
\text { obese } \\
\text { patients } \\
\text { between } \\
\text { ages } 20 \text { and } \\
50 \text { years old, } \\
\text { with BMI } \\
\text { between } 30 \\
\text { and } 50 \\
\mathrm{~kg} / \mathrm{m}^{2}\end{array}$ & $\begin{array}{l}\text { To prevent the } \\
\text { formation of } \\
\text { atelectasis in } \\
\text { obese patients } \\
\text { undergoing } \\
\text { laparoscopic } \\
\text { bariatric } \\
\text { surgery by } \\
\text { evaluating the } \\
\text { vital capacity } \\
\text { maneuver } \\
\text { (VCM), } \\
\text { followed by } \\
\text { different levels } \\
\text { of positive end- } \\
\text { expiratory } \\
\text { pressure } \\
\text { (PEEP). } \\
\text { *VCM=RM }\end{array}$ & $\begin{array}{l}\text { 1) Received the } \\
\text { VCM } \\
\text { maintained for } \\
7-8 \text { s applied } \\
\text { immediately } \\
\text { after intubation } \\
\text { plus ZEEP. } \\
\text { 2) Received the } \\
\text { VCM } \\
\text { maintained for } \\
7-8 \text { s applied } \\
\text { immediately } \\
\text { after intubation } \\
\text { plus } 5 \text { cmH2O } \\
\text { of PEEP. } \\
\text { 3) Received the } \\
\text { VCM } \\
\text { maintained for } \\
7-8 \mathrm{~s} \text { applied } \\
\text { immediately } \\
\text { after intubation } \\
\text { plus } 10 \mathrm{cmH} 2 \mathrm{O} \\
\text { of PEEP. } \\
\text { *VCM=RM }\end{array}$ & $\begin{array}{l}\text { Positive End } \\
\text { Expiratory } \\
\text { Pressure of } 10 \\
\text { cm H20 and the } \\
\text { use of a vital } \\
\text { capacity } \\
\text { maneuver } \\
\text { decreased the } \\
\text { presence of } \\
\text { atelectasis and } \\
\text { improved } \\
\text { arterial } \\
\text { oxygenation } \\
\text { and respiratory } \\
\text { mechanics. } \\
\text { Post-operative } \\
\text { atelectasis was } \\
\text { lower in the } \\
\text { PEEP } 10 \text { group. } \\
\text { No significant } \\
\text { differences in } \\
\text { post-operative } \\
\text { atelectasis in } \\
\text { PEEP } 5 \text { vs } \\
\text { ZEEP group. }\end{array}$ \\
\hline
\end{tabular}




\begin{tabular}{|c|c|c|c|c|}
\hline $\begin{array}{l}\text { Chalhoub, } \\
\text { et } \\
\text { al. (2007) }\end{array}$ & $\begin{array}{c}52 \text { adult } \\
\text { obese } \\
\text { patients with } \\
\text { BMI }>40 \\
\mathrm{~kg} / \mathrm{m}^{2}, \text { ASA } \\
3, \\
\text { undergoing } \\
\text { open } \\
\text { bariatric } \\
\text { surgery }\end{array}$ & $\begin{array}{l}\text { To assess the } \\
\text { effects of } \\
\text { PEEP, } \\
\text { immediately } \\
\text { after vital } \\
\text { capacity } \\
\text { maneuvers, on } \\
\text { arterial } \\
\text { oxygenation in } \\
\text { morbidly obese } \\
\text { patients } \\
\text { undergoing } \\
\text { open bariatric } \\
\text { surgery. }\end{array}$ & $\begin{array}{l}\text { 1) PEEP of } 8 \\
\text { mmHg was } \\
\text { added to } \\
\text { ventilation } \\
\text { regimen } \\
\text { 2) A vital } \\
\text { capacity } \\
\text { maneuver was } \\
\text { applied before } \\
\text { adding PEEP } \\
\text { of } 8 \text { mmHg to } \\
\text { ventilation } \\
\text { regimen. } \\
\text { *VCM = RM }\end{array}$ & $\begin{array}{l}\text { Positive End } \\
\text { Expiratory } \\
\text { Pressure with } \\
\text { the use of a } \\
\text { vital capacity } \\
\text { maneuver } \\
\text { increased } \\
\text { oxygenation } \\
\text { and decreased } \\
\text { atelectasis. }\end{array}$ \\
\hline $\begin{array}{l}\text { Futier, et } \\
\text { al. } \\
(2011)\end{array}$ & $\begin{array}{c}70 \text { adult } \\
\text { patients with } \\
\mathrm{BMI}>/=\text { to } \\
40 \mathrm{~kg} / \mathrm{m} 2, \\
\mathrm{ASA} 2-3, \\
\text { scheduled } \\
\text { for } \\
\text { laparoscopic } \\
\text { sleeve } \\
\text { gastrectomy } \\
\text { or Roux-en- } \\
\text { Y gastric } \\
\text { bypass }\end{array}$ & $\begin{array}{l}\text { To determine } \\
\text { whether } \\
\text { noninvasive } \\
\text { positive } \\
\text { pressure } \\
\text { ventilation } \\
\text { (NPPV) with a } \\
\text { recruitment } \\
\text { maneuver } \\
\text { (RM) improve } \\
\text { oxygenation } \\
\text { and end- } \\
\text { expiratory lung } \\
\text { volume } \\
\text { compared with } \\
\text { conventional } \\
\text { preoxygenation } \\
\text { at induction of } \\
\text { anesthesia }\end{array}$ & $\begin{array}{c}\text { 1) } \\
\text { Conventional } \\
\text { preoxygenation } \\
\text { with } \\
\text { spontaneous } \\
\text { breathing via } \\
\text { facemask } \\
\text { 2) Noninvasive } \\
\text { positive } \\
\text { pressure } \\
\text { ventilation } \\
\text { (NPPV) } \\
\text { 3) NPPV with } \\
\text { recruitment } \\
\text { maneuver }\end{array}$ & $\begin{array}{c}\text { Noninvasive } \\
\text { positive } \\
\text { pressure } \\
\text { ventilation } \\
\text { improves } \\
\text { arterial } \\
\text { oxygenation } \\
\text { and end } \\
\text { expiratory lung } \\
\text { volume. NPPV } \\
\text { combined with } \\
\text { a RM further } \\
\text { improves } \\
\text { oxygenation } \\
\text { after tracheal } \\
\text { intubation. }\end{array}$ \\
\hline
\end{tabular}




\begin{tabular}{|c|c|c|c|c|}
\hline $\begin{array}{l}\text { Reinius, et } \\
\text { al. } \\
\text { (2009) }\end{array}$ & $\begin{array}{c}30 \text { adult } \\
\text { patients } \\
\text { between the } \\
\text { ages } 25 \text { and } \\
54 \text { years old } \\
\text { with a BMI } \\
>40 \mathrm{~kg} / \mathrm{m} 2, \\
\text { ASA } 2-3, \\
\text { scheduled } \\
\text { for gastric } \\
\text { bypass } \\
\text { surgery en- } \\
\text { Roux }\end{array}$ & $\begin{array}{l}\text { To assess } \\
\text { whether a } \\
\text { recruitment } \\
\text { maneuver } \\
\text { followed by } \\
\text { PEEP would be } \\
\text { the most } \\
\text { efficient way to } \\
\text { improve } \\
\text { respiratory } \\
\text { function by } \\
\text { reducing } \\
\text { atelectasis in } \\
\text { morbidly obese } \\
\text { patients during } \\
\text { anesthesia and } \\
\text { paralysis }\end{array}$ & $\begin{array}{l}\text { 1) Received } \\
\text { positive end- } \\
\text { expiratory } \\
\text { pressure } \\
\text { (PEEP) of } 10 \\
\text { cmH2O } \\
\text { 2) Received } \\
\text { recruitment } \\
\text { maneuver } \\
\text { (RM) + zero } \\
\text { end-expiratory } \\
\text { pressure } \\
\text { 3) RM+PEEP }\end{array}$ & $\begin{array}{l}\text { RM without } \\
\text { PEEP did not } \\
\text { improve } \\
\text { atelectasis. } \\
\text { Both PEEP } \\
\text { alone and PEEP } \\
\text { with RM } \\
\text { improved } \\
\text { arterial } \\
\text { oxygenation } \\
\text { and decreased } \\
\text { atelectasis. } \\
\text { Improvement in } \\
\text { oxygenation } \\
\text { and decreased } \\
\text { atelectasis was } \\
\text { greater with the } \\
\text { use of PEEP + } \\
\text { RM vs PEEP } \\
\text { alone. . }\end{array}$ \\
\hline
\end{tabular}




\section{Appendix C}

CASP Checklist

\begin{tabular}{|c|c|c|c|c|}
\hline Study title 1 & \multicolumn{4}{|c|}{$\begin{array}{l}\text { The effects of the alveolar recruitment maneuver and positive end-expiratory pressure } \\
\text { on arterial oxygenation during laparoscopic bariatric surgery }\end{array}$} \\
\hline Study ID & \multicolumn{4}{|l|}{ Whalen, et al. (2006) } \\
\hline \multicolumn{2}{|c|}{ (A) Are the results of the trial valid? } & Yes & Can't tell & No \\
\hline \multicolumn{2}{|c|}{ 1. Did the trial address a clearly focused issue? } & $\mathbf{X}$ & & \\
\hline \multicolumn{2}{|c|}{$\begin{array}{l}\text { 2. Was the assignment of patients to treatments } \\
\text { randomized? }\end{array}$} & $\mathbf{X}$ & & \\
\hline \multicolumn{2}{|r|}{$\begin{array}{l}\text { 3. Were patients, health workers and study personnel } \\
\text { blinded? }\end{array}$} & $\mathbf{X}$ & & \\
\hline \multicolumn{2}{|r|}{ 4. Were the groups similar at the start of the trial? } & $\mathbf{X}$ & & \\
\hline \multicolumn{2}{|r|}{$\begin{array}{l}\text { 5. Aside from the experimental intervention, were the groups } \\
\text { treated } \\
\text { equally? }\end{array}$} & $\mathbf{X}$ & & \\
\hline \multicolumn{2}{|r|}{$\begin{array}{l}\text { 6. Were all the patients who entered the trial properly } \\
\text { accounted for } \\
\text { at its conclusion? }\end{array}$} & $\mathbf{X}$ & & \\
\hline \multicolumn{5}{|c|}{ (B) What are the results? } \\
\hline \multicolumn{5}{|c|}{ 7. How large was the treatment effect? } \\
\hline \multicolumn{5}{|c|}{ Significant; RM increased respiratory system dynamic compliance (by app. $40 \%$ ) } \\
\hline \multicolumn{4}{|c|}{$\mathrm{P}<0.01$} & \\
\hline \multicolumn{2}{|c|}{ (C) Will the results help locally? } & Yes & Can't tell & \\
\hline \multicolumn{2}{|r|}{$\begin{array}{l}\text { 9. Can the results be applied in your context or to the local } \\
\text { population? }\end{array}$} & $\mathbf{X}$ & & \\
\hline \multicolumn{2}{|r|}{ 10. Were all clinically important outcomes considered? } & $\mathbf{X}$ & & \\
\hline \multicolumn{2}{|c|}{ 11. Are the benefits worth the harms and costs? } & $\mathbf{X}$ & & \\
\hline
\end{tabular}




\begin{tabular}{|c|c|c|c|c|}
\hline Study title 2 & \multicolumn{4}{|c|}{$\begin{array}{l}\text { Effect of vital capacity manoeuvres on arterial oxygenation in morbidly obese patients } \\
\text { undergoing open bariatric surgery }\end{array}$} \\
\hline Study ID & \multicolumn{4}{|l|}{ Chalhoub, et al. (2007) } \\
\hline \multicolumn{2}{|c|}{ (A) Are the results of the trial valid? } & Yes & Can't tell I & No \\
\hline \multicolumn{2}{|c|}{ 1. Did the trial address a clearly focused issue? } & $\mathbf{X}$ & & \\
\hline \multicolumn{2}{|c|}{$\begin{array}{l}\text { 2. Was the assignment of patients to treatments } \\
\text { randomized? }\end{array}$} & $\mathbf{X}$ & & \\
\hline \multicolumn{2}{|r|}{$\begin{array}{l}\text { 3. Were patients, health workers and study personnel } \\
\text { blinded? }\end{array}$} & $\mathbf{X}$ & & \\
\hline \multicolumn{2}{|r|}{ 4. Were the groups similar at the start of the trial? } & $\mathbf{X}$ & & \\
\hline \multicolumn{2}{|c|}{$\begin{array}{l}\text { 5. Aside from the experimental intervention, were the } \\
\text { groups treated } \\
\text { equally? }\end{array}$} & $\mathbf{X}$ & & \\
\hline \multicolumn{2}{|c|}{$\begin{array}{l}6 . \text { Were all the patients who entered the trial properly } \\
\text { accounted for } \\
\text { at its conclusion? }\end{array}$} & $\mathbf{X}$ & & \\
\hline \multicolumn{5}{|c|}{ (B) What are the results? } \\
\hline \multicolumn{5}{|c|}{ 7. How large was the treatment effect? } \\
\hline \multicolumn{5}{|c|}{$\begin{array}{l}\text { Arterial oxygenation parameters were significantly improved in the group that received a } \\
\text { recruitment maneuver in addition to PEEP. }\end{array}$} \\
\hline \multicolumn{5}{|c|}{ 8. How precise was the estimate of the treatment effect? } \\
\hline \multicolumn{5}{|c|}{$\mathrm{P}<0.05$} \\
\hline \multicolumn{2}{|c|}{ (C) Will the results help locally? } & Yes & Can't tell I & \\
\hline \multicolumn{2}{|r|}{$\begin{array}{l}\text { 9. Can the results be applied in your context or to the local } \\
\text { population? }\end{array}$} & $\mathbf{X}$ & & \\
\hline \multicolumn{2}{|r|}{ 10. Were all clinically important outcomes considered? } & $\mathbf{X}$ & & \\
\hline \multicolumn{2}{|r|}{ 11. Are the benefits worth the harms and costs? } & $\mathbf{X}$ & & \\
\hline
\end{tabular}




\begin{tabular}{|c|c|c|c|c|}
\hline Study title 3 & $\begin{array}{l}\text { Intraoperative ventilatory strategies for prevention of pulmon } \\
\text { patients undergoing laparoscopic bariatric surgery }\end{array}$ & $y$ atel & tasis in obese & \\
\hline Study ID & Taleb, et al. (2009) & & & \\
\hline (A) Are the & results of the trial valid? & Yes & Can't tell & No \\
\hline 1. Di & the trial address a clearly focused issue? & $\mathbf{X}$ & & \\
\hline $\begin{array}{l}\text { 2. W: } \\
\text { rand }\end{array}$ & $\begin{array}{l}\text { is the assignment of patients to treatments } \\
\text { mized? }\end{array}$ & $\mathbf{X}$ & & \\
\hline $\begin{array}{l}\text { 3.W } \\
\text { blind }\end{array}$ & $\begin{array}{l}\text { re patients, health workers and study personnel } \\
\text { ed? }\end{array}$ & $\mathbf{X}$ & & \\
\hline 4. $\mathrm{W}_{\mathrm{c}} \mathrm{r}-\mathrm{a}$ & re the groups similar at the start of the trial? & $\mathbf{X}$ & & \\
\hline $\begin{array}{l}\text { 5. Asi } \\
\text { treat }\end{array}$ & $\begin{array}{l}\text { de from the experimental intervention, were the groups } \\
\text { d equally? }\end{array}$ & $\mathbf{X}$ & & \\
\hline $\begin{array}{l}\text { 6. We } \\
\text { accot }\end{array}$ & $\begin{array}{l}\text { re all the patients who entered the trial properly } \\
\text { inted for at its conclusion? }\end{array}$ & $\mathbf{X}$ & & \\
\hline (B) What ar & e the results? & & & \\
\hline 7. Hor & v large was the treatment effect? & & & \\
\hline $\begin{array}{l}\text { Signifi } \\
\text { compa }\end{array}$ & $\begin{array}{l}\text { ant; PEEP } 10 \text { is effective in preventing desaturation, chest inf } \\
\text { atively, as well as, significantly decreasing the formation of at }\end{array}$ & $\begin{array}{l}\text { tion a } \\
\text { ectasi }\end{array}$ & bronchospasn & \\
\hline 8. Ho & w precise was the estimate of the treatment effect? & & & \\
\hline $\mathrm{P}<0$ & & & & \\
\hline (C) Will the & results help locally? & Yes & Can't tell & No \\
\hline $\begin{array}{l}\text { 9. Ca } \\
\text { popul }\end{array}$ & $\begin{array}{l}\text { the results be applied in your context or to the local } \\
\text { ation? }\end{array}$ & $\mathbf{X}$ & & \\
\hline 10. $\mathrm{H}$ & ere all clinically important outcomes considered? & & & $\mathbf{X}$ \\
\hline 11. A & re the benefits worth the harms and costs? & $\mathbf{X}$ & & \\
\hline
\end{tabular}




\begin{tabular}{|c|c|c|c|c|}
\hline Study title 4 & \multicolumn{4}{|c|}{$\begin{array}{l}\text { Prevention of atelectasis in morbidly obese patients during general anesthesia and } \\
\text { paralysis }\end{array}$} \\
\hline Study ID & \multicolumn{4}{|l|}{ Reinius, et al. (2009) } \\
\hline \multicolumn{2}{|c|}{ (A) Are the results of the trial valid? } & Yes & Can't tell & No \\
\hline \multicolumn{2}{|c|}{ 1. Did the trial address a clearly focused issue? } & $\mathbf{X}$ & & \\
\hline \multicolumn{2}{|c|}{$\begin{array}{l}\text { 2. Was the assignment of patients to treatments } \\
\text { randomized? }\end{array}$} & $\mathbf{X}$ & & \\
\hline \multicolumn{2}{|c|}{$\begin{array}{l}\text { 3. Were patients, health workers and study personnel } \\
\text { blinded? }\end{array}$} & $\mathbf{X}$ & & \\
\hline \multicolumn{2}{|c|}{ 4. Were the groups similar at the start of the trial? } & $\mathbf{X}$ & & \\
\hline \multicolumn{2}{|c|}{$\begin{array}{l}\text { 5. Aside from the experimental intervention, were the } \\
\text { groups treated equally? }\end{array}$} & $\mathbf{X}$ & & \\
\hline \multicolumn{2}{|c|}{$\begin{array}{l}\text { 6. Were all the patients who entered the trial properly } \\
\text { accounted for at its conclusion? }\end{array}$} & $\mathbf{X}$ & & \\
\hline
\end{tabular}

(B) What are the results?

7. How large was the treatment effect?

A recruitment maneuver followed by PEEP caused a sustained increase in arterial oxygenation.

8. How precise was the estimate of the treatment effect?

$\mathrm{P}<0.0001$

(C) Will the results help locally?

\begin{tabular}{l|c|c|c|}
\hline $\begin{array}{l}\text { 9. Can the results be applied in your context or to the local } \\
\text { population? }\end{array}$ & $\mathrm{X}$ & & \\
\hline 10. Were all clinically important outcomes considered? & $\mathrm{X}$ & & \\
\hline 11. Are the benefits worth the harms and costs? & $\mathrm{X}$ & & \\
\hline
\end{tabular}




\begin{tabular}{|l|l|l|l|}
\hline Study title 5 & $\begin{array}{l}\text { Noninvasive ventilation and alveolar recruitment maneuver improve respiratory function } \\
\text { during and after intubation of morbidly obese patients }\end{array}$ \\
\hline Study ID & Futier, et al. (2011) & Yes & Can't tell No \\
\hline (A) Are the results of the trial valid? & $X$ & & \\
\hline $\begin{array}{l}\text { 1. Did the trial address a clearly focused issue? } \\
\text { 2. Was the assignment of patients to treatments } \\
\text { randomized? }\end{array}$ & $X$ & & \\
\hline $\begin{array}{l}\text { 3.Were patients, health workers and study personnel } \\
\text { blinded? }\end{array}$ & $X$ & & \\
\hline $\begin{array}{l}\text { 4. Were the groups similar at the start of the trial? } \\
\text { 5. Aside from the experimental intervention, were the groups } \\
\text { treated equally? }\end{array}$ & $X$ & & \\
\hline \\
$\begin{array}{l}\text { 6. Were all the patients who entered the trial properly } \\
\text { accounted for at its conclusion? }\end{array}$ & $X$ & & \\
\hline
\end{tabular}

(B) What are the results?

7. How large was the treatment effect?

Alveolar recruitment significantly improved respiratory function with application of positive pressure ventilation.

8. How precise was the estimate of the treatment effect?

$\mathrm{P}<0.001$

(C) Will the results help locally?

Yes

Can't tell No

9. Can the results be applied in your context or to the local population?

10. Were all clinically important outcomes considered?

11. Are the benefits worth the harms and costs? 